Program for Promoting Social Science Research

Aimed at Solutions of Near-Future Problems

Design of Interfirm Network to Achieve Sustainable Economic Growth

Working Paper Series No.5

The Effects of Collateral on Firm Performance

\author{
Arito Ono \\ Koji Sakai \\ and \\ lichiro Uesugi
}

February 10, 2011

Research Center for Interfirm Network

Institute of Economic Research, Hitotsubashi University

Naka 2-1, Kunitachi-city, Tokyo 186-8603, JAPAN

Tel: $+81-42-580-9145$

E-mail: hit-tdb-sec@ier.hit-u.ac.jp

http://www.ier.hit-u.ac.jp/ifn/ 


\title{
The Effects of Collateral on Firm Performance
}

\author{
Arito Ono ${ }^{\text {a }}$, Koji Sakai ${ }^{\mathrm{b}}$, and Iichiro Uesugi ${ }^{\mathrm{c}}$ \\ ${ }^{a}$ Institute for Monetary and Economic Studies, Bank of Japan, 2-1-1 \\ Nihonbashi-Hongokucho, Chuo-ku, Tokyo 103-8660 Japan. arito.ono@boj.or.jp \\ ${ }^{\mathrm{b}}$ Department of Economics, Kyoto Sangyo University, Motoyama, Kamigamo, Kita, Kyoto \\ 603-8555 Japan. ksakai@cc.kyoto-su.ac.jp \\ ${ }^{\mathrm{c}}$ Research Institute of Economy, Trade and Industry, 1-3-1, Kasumigaseki Chiyoda-ku, \\ Tokyo 100-8901 Japan. uesugi-iichiro@rieti.go.jp
}

\begin{abstract}
This paper examines how collateral and personal guarantees affect firms' ex-post performance employing a propensity score matching estimation approach. Based on a unique firm-level panel data set of more than 500 small-and-medium-sized borrower firms in Japan, we find that borrowers that provide collateral to lenders experience larger increases in profitability and reductions in riskiness than borrowers that do not. The main channel through which the borrower enhances its profitability is cost-cutting restructuring. These findings are consistent with the hypothesis that collateral reduces moral hazard by providing borrowers with an incentive to enhance their creditworthiness. We find little evidence that improvements in collateralized firms' performance are driven by the intensified monitoring on the part of lenders, or by borrowing firms’ access to larger amounts of credit.
\end{abstract}

JEL classification number: D82, G21, G30

Keywords: collateral, moral hazard, propensity score 


\section{Introduction}

How effective are collateral and personal guarantees in improving economic welfare? Empirically, this has long been an open question in corporate finance. It is also a question that has been increasing in relevance amidst the rapid expansion of small business credit scoring loans, which do not require collateral (Berger et al., 2006). While there is no question that the development of credit scoring technology has increased the availability of credit for small businesses, it is not clear if this is beneficial. It may be the case that easier access to credit is actually detrimental to small businesses, not to mention the economy as whole, if the diminished use of collateral has resulted in distorted lending decisions on the part of the lender and/or has induced moral hazard on the part of the borrower.

A substantial number of theoretical studies, including Bester (1985), Boot et al. (1991) and Stulz and Johnson (1985), suggest that the use of loan securities such as collateral in an environment of asymmetric information leads to possible welfare gains by limiting adverse selection and moral hazard problems. For example, Boot et al. (1991) argue that collateral pledged by risky borrowers induces them to exert greater managerial effort in order to reduce the default probability, and thus attenuates the problem of moral hazard. Stulz and Johnson argue that collateral reduces perverse incentives for borrowers to choose risky projects at creditors' expense (asset substitution).

We should be able to capture this type of effect by observing the ex-post 
performance of borrowers who pledge collateral. Despite the large number of empirical studies on the use of collateral, however, little attention has been paid to the effect of collateral on the ex-post performance of borrowing firms. Exceptions to this are studies by Berger and Udell (1990), Berger et al. (2009), and Jiménez and Saurina (2004). These studies find that collateralized borrowers are more likely to go bankrupt than uncollateralized borrowers simply because they are riskier ex-ante (that is, when the loans are provided). In essence, the previous literature does not deal with possible selection bias and, thus, is not able to address whether collateral mitigates borrowers' ex-post moral hazard behaviors.

Against this background, this paper represents the first attempt to examine how the provision of collateral and personal guarantees affects borrowers' managerial incentives as well as their ex-post performance, while appropriately controlling for possible selection biases. In so doing, we construct a unique firm-level panel data set of more than 500 Japanese small and medium enterprises (SMEs) covering the years 2001-2005, based mainly on the Surveys of the Financial Environment (SFEs) conducted by the Small and Medium Enterprise Agency of Japan. The yearly SFEs are an ideal data source for our analysis, as the SMEs in Japan tend to be heavily dependent on collateralized bank loans. Moreover, by constructing a panel data set, we are able to identify the year in which borrowers pledge collateral, and to trace their ex-post performance after the loan is extended.

We deal with a possible selection bias problem by employing the propensity score 
matching estimation approach proposed by Rosenbaum and Rubin (1983). Propensity score matching has become a popular method for estimating treatment effects that address selection bias problems, and has been widely applied in a diverse range of fields. We first estimate propensity scores, which are the probabilities of a borrower pledging collateral conditional on the relevant covariates, including borrowers' characteristics. Next, we produce a match for each collateralized borrower by choosing non-collateralized borrowers with the "closest" propensity scores to that of the collateralized borrower. We use these collateralized borrowers as the treatment group and the selected uncollateralized borrowers as the control group. Finally, we observe the difference between the treatment group and the control group in terms of the changes (yearly differences) in their performance variables one year later.

Our main findings are summarized as follows. We find that riskier firms are more likely to pledge collateral and that those that pledge collateral improve their performance one year later. In order to clarify through what channels collateral improves ex-post firm performance, we posit the following empirical hypotheses that are based on the previous theoretical literature. First is the "moral hazard hypothesis," which predicts that collateral induces risky firms to increase managerial effort to avoid defaulting on a loan (Boot et al., 1991), or reduces risky firms’ incentives to engage in asset substitution (Stulz and Johnson, 1985). In either case, collateral improves borrower firms' ex-post performance. Second is the “monitoring hypothesis,” which argues that collateral enhances lenders’ monitoring incentive. 
This may occur because collateral is effective in making the loan senior to other creditors' claims and thus serves as an "reward" to information production by the collateralized lender (Longhofer and Santos, 2000), or because collateral is effective only if its value can be monitored (Rajan and Winton, 1995). Third is the "availability hypothesis," which predicts that collateral improves borrowing firms' access to larger amounts of credit and contributes to the realization of profitable business opportunities (Besanko and Thakor, 1987).

Similar to the moral hazard hypothesis, the monitoring and the availability hypotheses both predict that the performance of collateralized borrowers will improve. Unlike the moral hazard hypothesis, however, the latter two hypotheses predict that the improvements in borrowers' performance are driven by the lenders' behaviors. And our analysis focusing on monitoring frequency and the lending attitude of borrowers' main bank provide little empirical support for the monitoring and the availability hypotheses. We also find that the improvement of firm performance for collateralized borrowers is weaker for personal guarantees, presumably because our sample firms typically incur a large amount of debts that cannot be covered by personal assets of the business representative. To summarize our key result - we find evidence for the effectiveness of collateral in mitigating borrowers' moral hazard problems by increasing their managerial effort or by refraining from asset substitution.

The structure of the paper is as follows. Section 2 provides a description of the 
existing theoretical and empirical literature on collateral and personal guarantees. Section 3 posits our empirical hypotheses to be examined. Section 4 explains our data set and the empirical methodology employed, while Section 5 presents the empirical results accompanied by a variety of robustness checks. Section 6 concludes.

\section{Previous Literature}

There is an abundant theoretical and empirical literature on the use of collateral. We review three strands of literature that are relevant for our analysis on the relationship between collateral and the ex-post performance of borrower firms. These focus, respectively, on the relationship between collateral and borrowers' credit risk, the relationship between collateral and the lender's screening and monitoring activities, and the relationship between collateral and loan availability.

We begin with the literature on the relationship between collateral and borrowers' credit risk. Lending practitioners frequently point out that risky firms are more likely to pledge collateral. That is, financial institutions assess the riskiness of applicant firms in order to determine whether to extend secured loans, unsecured loans, or no loans at all. If a financial institution finds that an applicant qualifies for a secured loan, it will ask the prospective borrower to pledge collateral. Boot et al. (1991) develop a theoretical model of this "sorting-by-observed risk" practice. They consider the situation in which the quality of 
the borrower's project is known to both the borrower and the lender but the borrower's effort after the loan is extended is private information. The model of Boot et al. (1991) predicts that, in equilibrium, the safer borrower is offered an unsecured loan, while the riskier borrower is offered a collateralized loan, because it is the riskier borrower whose marginal return to effort is larger. ${ }^{1}$ Thus, collateral provides an incentive to limit moral hazard by the borrower. Stulz and Johnson (1985) argue that collateral is useful in mitigating another type of moral hazard: asset substitution. If the borrower's actions after the loan is extended are private information, then firms with little capital have incentives to choose risky projects or cash payouts at the expense of creditors. Collateral prevents firms from engaging in such asset substitution.

Based on Boot et al. (1991) and Stulz and Johnson (1985), we can make two empirical predictions. First, the provision of collateral is positively associated with the

\footnotetext{
${ }^{1}$ The "sorting-by-observed risk" hypothesis represents one convincing theory of what determines whether a borrower pledges collateral. However, there is another plausible hypothesis, in which borrower riskiness is assumed to be unobservable. This hypothesis is referred to as the "sorting-by-unobserved risk," or signaling, hypothesis. Bester (1985), for example, argues that collateral can produce sorting across borrower types when the pledging of collateral is costly. Similarly, Besanko and Thakor (1987) posit that in the case that lenders are at an informational disadvantage regarding borrowers' default probability, collateral can attenuate credit rationing. These theoretical studies suggest that there is a negative relationship between collateral and (unobservable) borrower riskiness, because safer borrowers tend to pledge collateral as a signaling device to inform lenders that they are actually less risky. However, there are few empirical studies that provide support for the "sorting-by-unobserved risk" hypothesis. One exception is the study by Jiménez et al. (2006), which examines how ex-post borrower riskiness is associated with the use of collateral and finds that, among sub-samples of young firms, safer borrowers are more likely to pledge collateral. Another exception is the study by Berger et al. (2009), which utilizes credit registry information about borrower risk that is unobservable by the lender. They find that, among sub-samples of borrowers with short relationships with the lender, safer borrowers are more likely to pledge collateral.
} 
borrower's ex-ante riskiness. Second, collateralized borrowers become less risky over time, because they make greater efforts to avoid defaulting and/or refrain from asset substitution. There are many studies providing empirical evidence for the first prediction, including the seminal work by Orgler (1970) as well as recent studies such as Berger and Udell (1990; 1995), Brick and Palia (2007), Jiménez et al. (2006), and Jiménez and Saurina (2004). However, there are few empirical studies that have investigated the ex-post performance of collateralized borrowers, exceptions being Berger and Udell (1990), Berger et al. (2009), and Jiménez and Saurina (2004). These studies find that the ex-post performance of collateralized borrowers, such as the probability of default, is worse than that of uncollateralized borrower, and they attribute this finding to the higher ex-ante riskiness of collateralized borrowers. In other words, there are no empirical studies which find ex-post improvements of collateralized borrowers' performance, presumably because it is difficult to control for the possible selection bias of collateral provision. In section 4, we attempt to circumvent the selection bias problem and disentangle the ex-post performance of collateralized borrowers from their ex-ante riskiness by employing the matching estimation approach.

The second strand of literature examines the relationship between collateral and the lender's screening and monitoring activities. Manove et al. (2001) investigate the relationship between the use of collateral and screening by the lender. They argue that collateral is considered as a substitute for the evaluation of borrowers' riskiness. Thus, banks that are 
highly protected by collateral may become "lazy" in the sense that they perform less screening of projects they finance than is socially optimal. Longhofer and Santos (2000) and Rajan and Winton (1995), on the other hand, show theoretically that collateral may serve as a contractual device to increase the lender's screening and monitoring incentive. Longhofer and Santos, for example, argue that collateral is effective in raising the bank's seniority in the presence of several creditors and enhances its screening and monitoring, because collateral serves as an instrument to "reward" information production by the lender. However, the empirical evidence on the relationship between collateral and lenders' screening and monitoring is mixed. Jiménez et al. (2006), for example, find that banks with a low level of expertise in small business lending use collateral as a substitute for poor evaluation capabilities, while Voordeckers and Steijvers (2006) suggest that the intensity of credit evaluation does not have a significant effect on whether loans are collateralized. Meanwhile, Ono and Uesugi (2009) find evidence that monitoring intensity by the main bank, as measured by the frequency of document submission, is positively associated with collateral being pledged.

Finally, many of the theoretical studies that provide a positive rationale for collateral predict that collateral increases loan availability. For example, Bester (1985) and Besanko and Thakor (1987) show that under informational asymmetry, collateral serves as a sorting device for borrowers' ex-ante riskiness and thus attenuates credit rationing, enabling them to 
implement projects with positive net present value (NPV). Similarly, Stulz and Johnson (1985) argue that, by providing collateral to the creditor, borrowers become less likely to suffer from the underinvestment problem. Focusing on lenders' incentives, Inderst and Mueller (2007) show that collateral raises the probability of loan approval and thus facilitates the financing of projects with a positive NPV. Contrary to these theoretical studies, the model of Manove et al. (2001) shows that "lenient" provision of secured credit may be bad for society because lenders approve projects with a negative NPV. By examining the ex-post performance of collateralized borrowers in comparison with that of uncollateralized borrowers, we seek to shed some light on this issue as well.

\section{Empirical Hypotheses}

Based on the theoretical literature on how ex-post borrower characteristics are affected by the use of collateral, we have several testable hypotheses. Our main focus is on the association between borrower riskiness and collateral. We posit the following theoretical predictions: ${ }^{2}$ Hypothesis 1 (Moral Hazard Hypothesis): Borrowers with high observed riskiness are more likely to pledge collateral and improve their performances afterward by exerting greater effort,

\footnotetext{
${ }^{2}$ As noted in footnote 1, there exists another important hypothesis, the "sorting-by-unobserved risk" hypothesis, which predicts that borrowers with low unobserved riskiness are more likely to pledge collateral. However, since it is difficult to identify borrowers' unobservable riskiness in our data set, we do not explicitly examine this hypothesis. We will briefly discuss how the "sorting-by-unobserved risk" hypothesis is related to our empirical results in footnote 15.
} 
resulting in increased profitability, and/or by refraining from asset substitution, resulting in reduced riskiness. Alternatively, if the lender requires observably risky borrowers to pledge collateral in order to reduce its risk exposure and to substitute for its monitoring effort, then there is no reduction in the ex-post riskiness of collateralized borrowers.

The reasoning underlying the first part of this hypothesis is based on Boot et al. (1991) and Stulz and Johnson (1985). Boot et al. (1991) argue that it is riskier borrowers that tend to provide collateral, and then choose a higher managerial effort level. The reason for this incentive effect is that collateralized borrowers would lose their pledged assets upon default and hence strive to decrease their default probability by increasing their efforts. Moreover, because the marginal decrease in default probability by choosing a higher effort level is larger for riskier firm, it is riskier borrowers that are more likely to pledge collateral. Stulz and Johnson consider the agency problem between firm owners and debt holders. Because of limited liability, firm owners may prefer to choose risky projects at the expense of lenders, and this agency problem is particularly acute for financially distressed firms. Collateral will prevent a distressed firm from engaging in such asset substitution, and thus riskier firms tend to pledge collateral more often.

The latter part of the hypothesis, which is based on the model by Manove, Padilla, and Pagano, emphasizes lenders' incentive to reduce their exposure to borrowers' credit risk. In this case, lenders who are protected by collateral may perform less screening and 
monitoring than is socially optimal, which results in a deteriorating ex-post performance of borrowers.

The next two hypotheses concern how collateralized borrowers improve their performance.

Hypothesis 2 (Monitoring Hypothesis): The performance of collateralized borrowers improves after the loan is made because they are subject to more intensive monitoring by financial institutions.

Hypothesis 3 (Availability Hypothesis): Collateralized borrowers experience a greater improvement in performance because they find it easier to gain approval for larger loan amounts.

Hypothesis 2 is based on the theoretical models of Longhofer and Santos (2000) and Rajan and Winton (1995), in which collateral serves as a contractual device to increase the lender's monitoring incentive. More intensive monitoring by the lender attenuates the problem of borrower moral hazard and thus improves borrowers' creditworthiness and performance. Another possible path for borrowers to improve their performance is through better access to funds in order to implement projects with positive net present value, which we posit in Hypothesis 3. Besanko and Thakor (1987), for example, show that collateral mitigates the problem of credit rationing and thus improves credit availability. Similarly, if collateral reduces the agency problem between shareholders and lenders, it also increases the 
provision of credit (Stulz and Johnson, 1985). By investing funds in projects with positive net present value, collateralized borrowers will improve their profitability and creditworthiness.

Hypotheses 2 and 3 are compatible with the first part of Hypothesis 1 in that all three hypotheses expect that the performance of collateralized borrowers will improve. In other words, they are not mutually exclusive: for example, lenders are eager to provide more funds to those who pledge collateral (Hypothesis 3), because the moral hazard incentive for such borrowers is curbed (Hypothesis 1). However, Hypotheses 2 and 3 contrast with the first part of Hypothesis 1 in that the improvements in borrowers' performance are driven by the lenders' incentives and actions such as their monitoring frequency and their willingness to supply larger loan amounts, while Hypothesis 1 focuses solely on borrowers' incentives.

\section{Data Set and Empirical Approach}

\subsection{Data}

We construct a firm-level panel data set to analyze the ex-post performance of borrowers. The data set is based on the Surveys of the Financial Environment (SFE) implemented by the Small and Medium Enterprise Agency of Japan in the years 2001-2004 and the Financial Information Database (FID) which covers the years 2001-2005 and is collated by Tokyo Shoko Research, Incorporated, a commercial credit research firm. The yearly SFE survey is based on a sample drawn from the FID, which contains the balance sheet and income 
statements of firms. The SFE asks a variety of detailed questions regarding the financial transactions between a borrower and its main bank, such as the usage of collateral and personal guarantees. By combining the SFE and the FID, we have a rich firm-level data set that includes not only the financial statements of surveyed firms but also qualitative information regarding their financial transactions.

For our analysis, we need information for at least three periods in order to examine the effect of collateral on borrowers' ex-post performance. That is, we need to know whether collateral is provided in periods $t-1$ and $t$ and the development of borrowers' performance between periods $t$ and $t+1$. Using the data in period $t-1$ and $t$, we identify the year in which borrowers newly pledged collateral (personal guarantees). In order to do so, observations of firms that used collateral (personal guarantees) in period $t-1$ are omitted. Then, we produce a "match" for each collateralized borrower with non-collateralized borrowers in period $t$ by estimating a probit model that takes account of the various factors that are likely to affect whether borrowers pledge collateral. Then, using the data from periods $t$ and $t+1$, we measure the effect of collateral on borrowers' ex-post performance by observing the difference between matched collateralized borrowers and non-collateralized borrowers.

Combining the SFE and FID and using five years of data, we construct three panel data sets for the years 2001-2003, 2002-2004, and 2003-2005. We then concatenate these three data sets into one panel data set. The initial year of each panel data set is labeled year 
$t-1$, the second year is year $t$, and the final year is year $t+1$. We add dummies representing the initial year in order to distinguish these three panel data sets with different starting years.

For our analysis, we exclude the following observations from our data set. First, observations where one or more of the variables (described in the next subsection) fall into either the upper or lower 0.5 percentile of the total distribution were omitted from the sample. Second, in order to focus on firms that mostly depend on bank loans for their financing, the sample is restricted to borrowers that fulfill the legal definition of SMEs in Japan, which is that the firm has either 300 or fewer employees or 300 million yen of registered capital or less. Third, the sample is confined to firms with positive borrowings outstanding; that is, firms whose short-term and long-term loans and discounted bills outstanding added up to zero are omitted from the sample.

Lastly, and most importantly, the effects of government credit guarantees on collateral need to be controlled for. We deal with this issue by omitting from the sample all observations of borrowers that made use of government guarantee programs in any way. ${ }^{3}$ We do so because loans covered by the credit guarantee program enjoy a 100 percent guarantee of principal and interest, meaning that lenders bear no credit risk for the guaranteed loan

\footnotetext{
${ }^{3}$ Note, however, that the borrowers not covered by government guarantees in any way are larger and less risky. Hence, limiting our sample to borrowers that do not use government credit guarantee programs at all may introduce a size bias in the sample. As a robustness check, we also employ another data set which excludes only borrowers whose entire loans were covered by government credit guarantees (see Section
} $5.3)$. 
amounts and thus have no incentive to require borrowers to pledge collateral.

\subsection{Variables}

After screening our data as aforementioned, we are left with 543 observations for the analysis on collateral and 766 observations for the analysis on personal guarantees. ${ }^{4}$ The variables we use are detailed as follows and their definitions are summarized in Table 1.

First, in order to distinguish whether a borrower's loan is collateralized or not, we use two binary variables: whether collateral is used $\left(\mathrm{COLL}_{t}\right)$ and whether personal guarantees are used $\left(G U A R_{t}\right)$. The SFE defines collateral as physical assets or securities that the creditor can sell in the event that the borrower defaults. A personal guarantee refers to a contractual obligation of the business representative to repay loans in the event of a default. The dummy variable $C O L L_{t}\left(G U A R_{t}\right)$ equals one if the borrower does not pledge collateral (personal guarantees) in year $t-1$ but newly pledges collateral (personal guarantees) in year $t$ to its main bank; COLL $L_{t}\left(G U A R_{t}\right)$ equals zero if the borrower does not pledge collateral (personal guarantees) in either year $t-1$ or $t$. In our sample, the number of borrowers that newly pledge collateral (personal guarantees) in year $t$ is 115 (179), while the number of borrowers that continue not to pledge collateral (personal guarantees) is 428 (587).

\footnotetext{
${ }^{4}$ The corresponding numbers of observations when we count borrowers whose entire portfolio of loans from their main banks is not completely guaranteed by the government are 701 (collateral) and 928 (personal guarantees). Descriptive statistics for this data set are presented in the Appendix Table.
} 
Second, we use two sets of variables to evaluate ex-post firm performance and to examine Hypothesis 1 . The first set of variables measures firm performance: the profitability of a firm as measured by the return on assets $\left(R O A_{t}\right.$ : the ratio of pre-tax operating profits to total assets) and the interest coverage ratio ( $I C O V E R_{t}$ : the ratio of pre-tax operating profits to interest expenses), and the creditworthiness of a firm as measured by the capital ratio ( $C A P_{t}$ : the ratio of capital to total assets). The second set of variables captures whether a firm is in financial distress. For this, we use several binary dummy variables, including a dummy indicating whether a borrower defaults a loan in year $t$ ( $\left.D E F A U L T_{t}\right)$, a dummy for a negative ROA ( $\left.R O A_{-} N G_{t}\right)$ meaning the firm is in deficit, a dummy for interest coverage being less than or equal to unity (ICOVER_SM ${ }_{t}$ ) meaning operating profit is insufficient to cover interest expenses, and a dummy for a negative capital ratio $\left(C A P_{-} N G_{t}\right)$, that is, the firm has negative net worth. Although our choice of these financial variables is somewhat arbitrary, they are conventionally used in credit risk analysis by practitioners and also used to measure the observable risk of the borrower in the previous studies (Berger and Udell, 1995; Brick and Palia, 2007)

Third, in order to investigate Hypotheses 2 and 3, the following variables are employed. Hypothesis 2 relates ex-post firm performance to the lender's monitoring activity. Our proxy variable for the lender's monitoring is the frequency of a firm's document submissions to its main bank $\left(D O C_{t}\right)$. $D O C_{t}$ ranges from a minimum index value of 1 for 
the lowest document submission frequency (once a year) to a maximum of 4 for the highest document submission frequency (once every one or two months). ${ }^{5}$ Hypothesis 3 attributes ex-post firm performance to the availability of credit to the borrower firm. We measure the availability of credit by an index variable of the main bank's response to a borrower's loan application $\left(R E S_{t}\right)$ and the fixed-asset ratio $\left(F I X E D_{t}\right)$. RES takes a value of 1 if an application was rejected or the loan amount was reduced, a value of 2 if a loan application was approved, and a value of 3 if the lender solicited the borrower to increase the loan amount. ${ }^{6}$ FIXED ${ }_{t}$ is the ratio of fixed tangible assets to total assets. We use this variable because if the collateral increases loan availability for borrower firms, then it is likely to result in increases in their fixed investment.

Finally, the following are the proxy variables we employ for borrower characteristics and the borrower-lender relationship that determine the use of collateral and personal guarantees in period $t$. Firm characteristic variables include the log of the number of

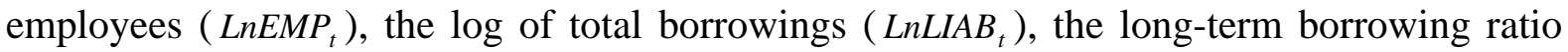

\footnotetext{
${ }^{5}$ We also employ an alternative definition of $D O C_{t}$, where it indicates document submission frequency in terms of months; for example we assign the value 12 if a borrower submit documents to its main bank once a year. The empirical results obtained are qualitatively the same in both cases, and we therefore only report the results for our main definition of $D O C_{t}$

${ }^{6}$ We also employ an alternative definition of $R E S_{t}$, where it is a binary dummy variable that takes a value of 1 if an application was rejected or the loan amount reduced and 0 otherwise. The empirical results obtained are qualitatively the same in both cases, and we therefore only report the results for our main definition of $R E S_{t}$.
} 
( $L O N G_{t}$ : the ratio of long-term loans whose maturity is more than 1 year to total assets), the land ratio ( $L A N D_{t}$ : the ratio of real estate holdings to total assets), the cash ratio ( $C A S H_{t}$ : the ratio of cash holdings to total assets), and the interest payment rate ( $R A T E_{t}$ : interest expenses divided by the total amount of borrowing). These variables are constructed from a firm's financial statements in the FID. ${ }^{7}$ To measure the extent of commingling risk of business assets and the personal assets of the owner that is likely to be positively associated with the use of personal guarantees, we construct a dummy variable that equals one if a family member of the CEO of the borrower firm is a major shareholder $\left(O W N E R_{t}\right)$. As proxies for the borrower-lender relationship, we use the number of banks with which the borrower has transactions $\left(B A N K S_{t}\right)$ and the log of the duration of the borrower-main bank relationship $\left(\operatorname{LnDURATION}_{t}\right)$. The underlying assumption is that the smaller the number of banks that a borrower has transactions with and the longer the years that a borrower has transactions with the main bank, the more solid are the borrower-lender relationships. Year and industry dummies as well as a dummy for the type of main bank are also included.

\subsection{Empirical Approach}

Using the data set just described, we proceed to examine the effect of borrowers' pledging of

\footnotetext{
${ }^{7}$ To be precise, there is a time lag (six to eight months in most cases) between variables constructed from FID and those from SFE. As such, using lagged explanatory variables in probit estimations for collateral (personal guarantees) in subsequent sections alleviates the possible endogeneity problems.
} 
collateral. Note, however, that a simple comparison of the ex-post performance of collateral users and non-users is not appropriate because of possible selection bias. For example, if the borrower firms that pledge collateral are riskier than those not pledging collateral, then a simple comparison of the ex-post performance between the two groups confounds ex-ante riskiness and ex-post riskiness (changes in borrowers' riskiness after the loan is extended). To circumvent the problem, we need to control for any possible selection bias in our estimation. To do so, we employ the matching estimation approach. The procedure is as follows:

(i) We implement a probit estimation that models the probability of borrowers' pledging collateral in year $t$ conditional on covariates observed in the same year. Borrowers that pledge collateral $\left(C O L L_{t}=1\right)$ are labeled treatment observations. We then attach a propensity score to each observation. The propensity score $e(\cdot)$ is defined as

$$
e\left(X_{t}\right) \equiv \operatorname{Pr}\left(C O L L_{t}=1 \mid X_{t}\right)
$$

where $X_{t}$ is a vector of covariates in the collateral equation.

(ii) Next, for each treatment observation, we identify matched observations from the uncollateralized borrower sample. The matched observations are those who have the "closest" propensity scores to a particular treatment observation and are labeled control observations. These matched observations are chosen from the same calendar year as the treatment observation. It should also be noted that we use a non-treated observation more than once as a control, that is, a non-treatment observation may be used as a control for one treatment 
observation and as a control for another treatment observation at the same time. There are several matching algorithms to find the "closest" control observations. As a base-line for our analysis, we employ $k$-nearest matching, in which the arbitrarily determined $k$ observations whose propensity scores are the closest to each treatment observation are chosen. ${ }^{8}$

(iii) Finally, we compare the change (yearly difference) in the ex-post performance variables of the treatment and the control group from year $t$ to year $t+1$. To be precise, to test Hypothesis 1, we use the difference-in-difference (DID) estimator regarding firms' ex-post performance variables described above, where the DID estimator is defined as $\Delta Y_{t+1}^{T, i}-\Delta Y_{t+1}^{C, i}$ where $Y$ indicates the performance variable and uppercase $T, i$ and $C, i$ stand for the treatment firm $i$ and its control group firms, respectively. In our analysis, the DID estimator is superior to the traditional matching estimator in that time-invariant biases before and after pledging collateral (unobserved risk, for instance) are differenced out between the treatment and the control group (Heckman et al., 1998).

We expect an improvement in the DID estimators if the moral hazard hypothesis applies. To examine the validity of Hypotheses 2 and 3, we calculate the DID with respect to the monitoring and availability variables. For Hypotheses 2 and 3, we measure the changes from year $t-1$ to $t$, because these hypotheses presume contemporaneous relationships between

\footnotetext{
${ }^{8}$ In this paper we use $k=5$. Because the results of our estimation may be sensitive to the matching algorithm we choose, as a robustness check, in Section 5.3 we also report results using different matching algorithms: 10-nearest matching, radius matching, and kernel matching.
} 
the proxy variables and the provision of collateral. We expect a more sizable increase of document submission frequency, a larger improvement of the main bank's lending attitude, and a more sizable increase of the fixed-asset ratio if these hypotheses hold.

One of the benefits of employing propensity score matching estimation is that we can match treatment and control observations using the scalar propensity score. The propensity score, which is the conditional probability of being treated given the value of observed characteristics, is a very useful variable in dealing with a highly dimensional vector of covariates. Rosenbaum and Rubin (1983) show that treatment observations (in our case those who pledged collateral) and control observations (those who did not pledge collateral) with the same propensity score value have the same distribution of the full vector of covariates. It is thus sufficient to match firms in terms of the propensity score in order to obtain the same probability distribution of covariates for treatment and control observations.

In propensity score matching, an assumption known as unconfoundedness has to be satisfied so that the differences in ex-post performance variables between the treated observations and the controlled observations with the same values for covariates are attributable to the treatment effect of providing collateral (Caliendo and Kopeinig, 2008). That is,

$$
\left(\Delta Y_{t+1}^{T}, \Delta Y_{t+1}^{C}\right) \perp C O L L_{t} \mid\left(X_{t}\right)
$$

Rosenbaum and Rubin (1983) shows that the assumption (2) is identical to the following 
condition:

$$
\left(\Delta Y_{t+1}^{T}, \Delta Y_{t+1}^{C}\right) \perp C O L L_{t} \mid e\left(X_{t}\right)
$$

Although there is no direct test for the unconfoundedness, this assumption indicates the need to control for all relevant variables $X_{t}$ that influence treatment assignments and ex-post performance variables. We believe that our data is rich enough to include all the necessary covariates. Furthermore, the DID matching estimator that we use allows for the existence of differences in time-invariant unobservable characteristics between the treatment and the control group.

In addition to unconfoundedness, the following balancing condition of pretreatment variables given the propensity score must be satisfied (Becker and Ichino, 2002):

$$
C O L L_{t} \perp X_{t} \mid e\left(X_{t}\right)
$$

In other words, for a given propensity score, treatment observations are randomly chosen, and therefore, the treatment sample and the non-treated sample are on average identical.

In order to verify that (4) holds, we implement the following testing procedure after the first step of the matching observation: (i) based on the estimated probit model, we split the sample such that the average propensity scores of the treated and non-treated groups do not differ, and (ii) within all intervals, test that the means of every element of $X_{t}$ do not differ significantly between treated and non-treated observations. If there are no statistically significant differences between the two, then we can proceed to estimate the treatment effect 
in the second step with some confidence.

\section{Results}

\subsection{Propensity Score Estimation}

We start from the propensity score estimation. Table 2 lists the means of the variables we use in this estimation, depending on whether a borrower pledges collateral (personal guarantee) at time $t$. As expected, there are large differences in means between collateralized borrowers and uncollateralized borrowers, and we will control for these differences by propensity score estimations below.

\section{(Insert Table 2)}

In our model, the propensity score is the conditional probability of a borrower pledging collateral and personal guarantees to its main bank in year $t$ given the values of observed borrower characteristics and the borrower-bank relationship in the same year. ${ }^{9}$ There are two dependent variables, a binary dummy variable on the use of collateral in year $t$ $\left(C O L L_{t}\right)$ and a binary variable on the use of personal guarantees in year $t\left(G U A R_{t}\right)$. Note that, as a result of the way we have constructed our data set, the values of $C O L L_{t-1}$ and $G U A R_{t-1}$ are zero.

\footnotetext{
${ }^{9}$ As noted in footnote 7, the simultaneity bias problem is subdued because there is a time lag (six to eight months in most cases) between variables constructed from financial statements (for example, debt capacity) and dummy variables for collateral and personal guarantees.
} 
Explanatory variables are as follows. First, we employ the following borrower

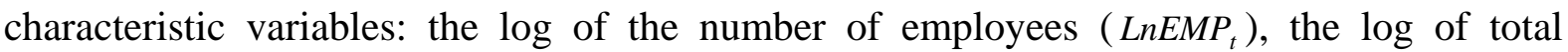
borrowings $\left(L n L I A B_{t}\right)$, the capital-asset ratio $\left(C A P_{t}\right)$, the long-term borrowing ratio $\left(L O N G_{t}\right)$, the land ratio $\left(L A N D_{t}\right)$, profitability in terms of ROA $\left(R O A_{t}\right)$ and the interest coverage ratio ( ICOVER $\left.R_{t}\right)$, liquidity as measured by the cash-to-asset ratio $\left(\mathrm{CASH}_{t}\right)$, the interest payment rate $\left(R A T E_{t}\right)$, and the dummy indicating whether a family member of the CEO is a major shareholder $\left(O W N E R_{t}\right)$. In addition, considering the possibility that very risky firms newly pledge collateral more often than the other firms, we use three dummy variables to identify borrowers in financial distress. These are a dummy for a negative ROA $\left(R O A_{-} N G_{t}\right)$, a dummy indicating whether the interest coverage is less than or equal to unity ( ICOVER_SM ${ }_{t}$ ), and a dummy indicating whether the capital ratio is negative ( $\left.C A P_{-} N G_{t}\right)$. Second, two variables representing the intimacy of borrower-lender relationships are used: the number of banks $\left(B A N K S_{t}\right)$ and the years of duration of the borrower-lender relationship in logarithm $\left(\operatorname{LnDURATION}_{t}\right)$. Third, to capture whether the collateral (personal guarantee) is pledged in tandem with the provision of personal guarantees (collateral), dummy variables for personal guarantees (collateral) in year $t-1$ and $t$ are included as explanatory variables in the collateral (personal guarantee) equation. Finally, year, industry, and regional dummies as well as dummies for the type of main bank are included.

The probit estimation results on the use of collateral and personal guarantees are 
presented in Table 3. In the estimation on the use of collateral, there are several significant coefficients. $L O N G_{t}$ is positive and significant, which is consistent with practitioners' observation that long-term loans often finance purchases of machinery or equipment and these physical assets tend to be used as collateral. Similarly, $L A N D_{t}$ is positive and significant, indicating that firms whose holdings of real estate make up a larger share of their assets are more likely to pledge collateral. Regarding the firm performance variables, a significant positive coefficient is obtained for ICOVER_SM $M_{t}$, while the coefficient on $I_{C O V E R_{t}}$ is insignificant. The significant positive coefficient on ICOVER_SM ${ }_{t}$ suggests that whether borrowers fall below the threshold where their operating profits are sufficient to cover interest expenses is a critical determinant of whether lenders require collateral. The result is in line with the previous studies that find the provision of collateral is positively associated with the observable risk of the borrower (Berger and Udell, 1995; Brick and Palia, 2007). LnDURATION $_{t}$ is positive and significant, implying that borrowers who have established a longer-term relationship with their main bank are more likely to pledge collateral. ${ }^{10}$ Finally, the coefficient on $G U A R_{t}$ is positive and significant, meaning that borrowers who pledge a personal guarantee to their main bank are likely to newly pledge

\footnotetext{
${ }^{10}$ Although a standard theory suggests that relationship lending alleviates the need to pledge collateral, existing empirical evidence on the relationship between the strength of relationship and collateral being pledged is mixed (Berger et al., 2009). Our result is consistent with Ono and Uesugi (2009) which also uses the Survey of the Financial Environment in 2002. They argue that, in the presence of other banks that also makes loans to the same borrower, collateral is complementary to relationship lending because it effectively raises the seniority of main bank's credit.
} 
collateral simultaneously.

(Insert Table 3)

In the estimation on the use of personal guarantees, there are several differences from the results for the collateral equation. Both $\operatorname{LnEMP}_{t}$ and $\operatorname{LnLIAB}_{t}$ have significant negative coefficients, implying that firms with fewer employees and smaller amounts of borrowing outstanding tend to pledge personal guarantees more often. In addition, the dummy variable $O W N E R_{t}$ has a significant positive coefficient. Owner-CEOs are less hesitant to pledge personal guarantees since they have a sizable stake in the firm. Taken together, the result suggests that firms' main bank tends to require personal guarantees from smaller firms that can be easily controlled by the owner-CEO, presumably in order to attenuate the risk of the commingling of representatives’ personal wealth and business assets. Although only weakly significant, the coefficient for the capital-asset ratio, $C A P_{t}$, is negative, indicating that firms with less capital are more likely to pledge personal guarantees. Finally, similar to the result for the collateral equation, the coefficient on $C O L L_{t}$ is positive and significant. Thus, borrowers who pledge collateral to their main bank are likely to newly pledge a personal guarantee simultaneously.

\subsection{Treatment Effect Estimation}

Having obtained the propensity score for each observation, we match each treatment 
observation of a borrower that pledges collateral (personal guarantees) in year $t$ with control observations of borrowers that do not pledge collateral (personal guarantees) in that year. There are 115 treatment observations that newly pledge collateral and 179 treatment observations that newly pledge personal guarantees. We choose five neighboring control observations for each treatment observation in the same calendar year in terms of the distance measured by the propensity scores.

For these treatment and control observations that are matched, in order to examine Hypothesis 1, we use several variables to measure the change in borrowers' performance between year $t$ and year $t+1$. First, for both the treatment and the control group, the change in the performance variables is measured by $\Delta R O A_{t+1}^{j}\left(\equiv R O A_{t+1}^{j}-R O A_{t}^{j}\right), \quad \Delta C A P_{t+1}^{j}$, and $\triangle I C O V E R_{t+1}^{j}$, where $j=\{T, C\}$ and $T$ and $C$ stand for the treatment and the control group, respectively. Because the change in the interest coverage ratio is also affected by the change in the interest payment rate, we also check $\triangle R A T E_{t+1}^{j}$. Second, we examine the change in the probability of financial distress. We use several ways to define borrower financial distress, including default, a negative capital ratio, interest coverage less than or equal to unity, and a negative ROA. We measure the probability of a borrower falling into a certain type of distress and then take the difference in this probability between year $t$ and year $t+1$. Hence, the change in distress probabilities is measured by $\Delta p_{t+1}^{j}(D E F A U L T=1),{ }^{11} \Delta p_{t+1}^{j}\left(C A P_{-} N G=1\right)$,

\footnotetext{
${ }^{11}$ Since we do not have data on defaults in year $t, \Delta p_{t+1}^{j}(D E F A U L T=1)$ is actually
} 
$\Delta p_{t+1}^{j}\left(I C O V E R_{-} S M=1\right)$, and $\Delta p_{t+1}^{j}\left(R O A_{-} N G=1\right)$, where $j=\{T, C\}$. Finally, for both performance variables and financial distress variables, we take differences in the change in these variables between the treatment and the control group; for example, in the case of ROA, we measure $\Delta R O A_{t+1}^{T}-\Delta R O A_{t+1}^{C}$. We then use these to estimate the treatment effect of pledging collateral or personal guarantees.

Turning to the results, we begin with the treatment effect of pledging collateral, shown in Table 4. Note that at time $t$, differences in means between the treatment group and the control group are statistically insignificant, because of the balancing condition (equation (4)) we impose. Among the borrower performance variables, $\triangle R O A_{t+1}^{T}$ is higher than $\Delta R O A_{t+1}^{C}$ by 1.2 percentage points, which is the treatment effect and statistically significant at the 5 percent level. $\triangle C A P_{t+1}^{T}$ is also higher than $\Delta C A P_{t+1}^{C}$, by 1.9 percentage points, and the difference is statistically significant at the 5 percent level. $\triangle \operatorname{ICOVER} R_{t+1}^{T}$ is also higher than $\triangle I C O V E R_{t+1}^{C}$, but the effect is not statistically significant. Note that $\triangle R A T E_{t+1}^{T}$ is higher than $\triangle R A T E_{t+1}^{C}$ by a statistically significant 0.7 percentage points, implying that borrowers pledging collateral face a larger increase in interest payment rates than those who do not. Looking at the variables of financial distress probabilities, we find that all of them show that borrowers in the treatment group see a greater reduction in their probability of falling into financial distress than those in the control group. Specifically, the differences between the $p_{t+1}^{j}(D E F A U L T=1)$. 
treatment and the control group are significant at the 1 percent level for $\Delta p_{t+1}^{j}\left(I C O V E R_{-} S M=1\right)$ and significant at the 5 percent level for $\Delta p_{t+1}^{j}\left(R O A_{-} N G=1\right)$.

Finally, in order to examine Hypotheses 2 and 3, we estimate the treatment effect measuring the changes in financial conditions from year $t-1$ to year $t$. We do so because these hypotheses presume contemporaneous relationships between the proxy variables employed and the pledging of collateral and personal guarantees. Table 4 shows that the difference between the treatment and the control group is negative for $\Delta D O C_{t}^{j}$, meaning that collateralized borrowers are somewhat less frequently monitored by their main banks than non-collateralized borrowers. This contradicts the monitoring hypothesis, although the effect is statistically insignificant. Turning to the credit availability variables, consistent with the prediction that collateralized borrowers will experience an improvement in credit availability, the differences between the treatment and the control group are positive both for the index variable indicating main banks' response to borrowers' loan applications, $\Delta R E S_{t}^{j}$, and for the fixed asset ratio, $\triangle F I X E D_{t}^{j}$, but these differences are statistically insignificant. Thus, we cannot state that for collateralized borrowers the main bank exerts either more or less intensive monitoring effort or that the bank becomes either more or less accommodative in approving loans.

(Insert Table 4)

Next, we present the results for the treatment effect of pledging personal guarantees, 
shown in Table 5. In comparison with the results obtained for collateral, the number of variables for which the difference between the treatment and the control group is statistically significant is limited. Among the borrower performance variables, $\triangle R O A_{t+1}^{T}$ and $\triangle C A P_{t+1}^{T}$ are slightly higher than the control group counterparts, but the difference is not significant. Moreover, $\triangle I C O V E R_{t+1}^{T}$ is lower than $\triangle I C O V E R_{t+1}^{C}$ and the effect is weakly significant at the 10 percent level, hinting at a deterioration in the ex-post performance of borrowers that pledge personal guarantees. A likely explanation for this finding is that, because our sample firms consist of fairly large SMEs and the size of their debts outstanding (median is 274 million yen, approximately 2.74 million dollars) often exceeds the amount to be covered by personal assets of the business representative, the effect of personal guarantees in reducing borrower moral hazard is weak. ${ }^{12}$

Among the variables representing the probabilities of financial distress, the probabilities of falling into negative net worth $\left(\triangle C A P_{t+1}^{j}\right)$ and a profit deficit $\left(\triangle R O A_{t+1}^{j}\right)$ display a larger decrease for the treatment group than the control group, but the margins are not significant. Finally, regarding the variables on monitoring frequency and credit availability,

\footnotetext{
${ }^{12}$ As suggested from the probit estimation (Table 3), main banks require personal guarantees from smaller firms whose business is strongly controlled by the business representative. Variables to examine the moral hazard hypothesis for such firms may be different from standard financial ratios. As an alternative test of treatment effects for personal guarantees, we also employ variables that represent compensations to the business representative and executives, such as the ratio of dividends to assets, executive compensations to assets, expenses account spending to assets. However, we do not obtain any significant result that supports the moral hazard hypothesis (results not reported).
} 
the coefficient obtained for $\triangle D O C_{t}^{j}$ is consistent with Hypothesis 2 but the effect is not significant, and the signs of the coefficients on $\triangle R E S_{t}^{j}$ and $\triangle F I X E D_{t}^{j}$ are contradictory to Hypothesis 3.

(Insert Table 5)

\subsection{Robustness Check}

The results presented in the previous subsection are based on a sample which completely excludes borrowers that received government credit guarantees. Restricting our sample in this way is effective for controlling for the distorting influence of government guarantees on borrowers' decisions with regard to the use of collateral or personal guarantees. However, eliminating all borrowers with loans that are subject to government guarantees, even when these loans make up only a miniscule fraction of loan portfolios, comes at a cost, namely that the sample is limited to larger and less risky SMEs.

Hence, as a robustness check of our results, we conduct similar estimations in which the potentially distorting role of government guarantees is controlled for in a less stringent manner. That is, we exclude from the sample only those borrowers whose entire loans supplied by their main bank are covered by government credit guarantees. Extending loans to firms whose entire loans are covered by government guarantees is riskless for banks. In this case, banks have no incentive to require borrowers to pledge collateral or personal guarantees. 
In contrast, banks do have incentives to require collateral or personal guarantees when not all of a borrower's loans are covered by government guarantee.

The results of these estimations, shown in Tables 6 (the propensity score estimation) and 7 (the treatment effect estimation), are qualitatively not very different from the base case results for the sample consisting only of firms with no government guarantees at all. ${ }^{13}$ In the first-step probit estimation to obtain propensity scores, we find that the overall fitness of the equations improves as indicated by the increase in Pseudo R-squared. The level of significance of most explanatory variables is qualitatively the same as in the base case, except for some firm performance variables in the collateral equation. That is, in contrast with the result in the base case, the positive coefficient on ICOVER_SM $M_{t}$ becomes insignificant. Moreover, the coefficient on $R O A_{t}$ is positive and significant, implying that more profitable firms tend to pledge collateral more often. The added explanatory variable $G O V G U A R_{t}$, which is the binary dummy variable representing whether a borrower partially uses government credit guarantees for loans supplied by the main bank, has a positive and significant coefficient both in the collateral and the personal guarantees equation: borrowers using government guarantees tend to pledge collateral and personal guarantees more often than borrowers that do not rely on such guarantees. Turning to the second-step estimation to obtain the treatment effect, we observe that the effect is qualitatively the same but not as

\footnotetext{
${ }^{13}$ The summary statistics for the sample consisting of firms that partially use government guarantees are presented in the Appendix Table.
} 
statistically significant as in the base case estimations. With respect to the treatment effects for collateral, all the coefficients for the ex-post firm performance variables have the same signs as in the baseline estimation except for $\triangle C A P_{t+1}^{j}$, whose coefficient is reversed but is statistically insignificant. The profitability of collateralized borrowers improves and their probability of financial distress declines when compared with non-collateralized borrowers, but the size of the coefficient becomes smaller and their statistical significance decreases. With respect to Hypotheses 2 and 3, there is no strong supportive evidence: the signs of $\triangle D O C_{t}^{j}, \triangle R E S_{t}^{j}, \triangle F I X E D_{t}^{j}$ are consistent with the monitoring and availability hypotheses, but their effects are not statistically significant. Regarding personal guarantees, we find some evidence that the probability of being in financial distress is higher for those firms that pledge personal guarantees: the coefficients on $\Delta p_{t+1}^{j}\left(I C O V E R_{-} S M=1\right)$ and $\Delta p_{t+1}^{j}\left(R O A_{-} N G=1\right)$ are positive and significant. In contrast with the positive treatment effects for collateral, we cannot find evidence that personal guarantees mitigate moral hazard on the part of borrowers and improve their ex-post performance.

(Insert Tables 6 and 7)

As another robustness check of the results obtained in the base case, we estimate the treatment effects for collateral and personal guarantees using different matching algorithms: 10-nearest matching, Kernel matching, and radius matching. For our robustness check using different matching algorithms, we use the sample consisting only of firms that used no 
government credit guarantees at all. Kernel matching is a nonparametric estimation technique that uses the weighted averages of nearly all observations from the non-treated observations to construct the control group. Radius matching chooses all observations that lie within an arbitrarily determined "radius (propensity score range)" as the control group.

The results using these alternative matching algorithms are displayed in Tables 8 and 9, presenting the treatment effect estimations for collateral and personal guarantees, respectively. Although there are a few cases in which the sign or the statistical significance of coefficients is different from the 5-nearest matching estimation in Section 5.2 (Tables 4 and 5), the results are qualitatively the same. Collateralized borrowers experience a greater improvement in ex-post performance than non-collateralized borrowers, and this treatment effect is weaker for personal guarantees. ${ }^{14}$

(Insert Tables 8 and 9)

\subsection{Discussion}

On balance, the results of the above estimations indicate that the treatment effect of providing collateral is that it lowers the riskiness and increases the profitability of firms that pledge

\footnotetext{
${ }^{14}$ One notable exception is the treatment effect for personal guarantees in the estimation using radius matching. Here, we observe that the probabilities of default and negative net worth become smaller for the treatment group (borrowers that pledge personal guarantees). These findings are consistent with Hypothesis 1 . However, because we do not obtain similar results from the other matching procedures, we decided not to attach much importance to this result.
} 
collateral. On the other hand, these effects are tenuous in the case of personal guarantees. Given these results, our next task is to consider how these improvements are achieved. Our main hypothesis (Hypothesis 1) is that the effects are brought about by the reduction of moral hazard on the part of borrowers. The alternative hypotheses are the following: the monitoring hypothesis, according to which collateral or personal guarantees induce banks to exert greater monitoring effort, which in turn results in borrowers exercising greater discipline in reducing their riskiness (Hypothesis 2); and the availability hypothesis, according to which borrowers obtain better access to funds and thus improve their quality by investing in projects with positive net present values (Hypothesis 3). In contrast with Hypothesis 1, these hypotheses focus on how lenders’ actions affect borrowers’ performances.

In the propensity score estimation, pledging collateral is positively associated with observed borrower riskiness. And in the treatment effect estimation, borrowers with collateral see an increase in their profitability and a reduction in their riskiness as represented by the probability of falling into financial distress. These results are consistent with the predictions of Hypothesis $1 .^{15}$

The variables we employed to examine Hypotheses 2 and 3 are $\triangle D O C_{t}^{j}, \Delta R E S_{t}^{j}$,

\footnotetext{
${ }^{15}$ Admittedly, even though the empirical evidence of the propensity score and treatment effect estimations supports Hypothesis 1, we cannot reject the signaling hypothesis which was briefly referred to in footnote 1. The DID estimator might difference out time-invariant unobserved risk between the treatment and the control group, but it is still possible that borrowers who appear risky use collateral to signal that they are actually riskless and reveal that they are indeed riskless through their ex-post performance.
} 
and $\triangle F I X E D_{t}^{j}$. The signs of these variables are inconsistent with the hypotheses in some cases, and the coefficients are consistent but insignificant in other cases. Thus, we cannot find supporting evidence for these hypotheses.

Therefore, we may infer that collateralized borrowers improve their performance by their own managerial effort or by refraining from asset substitution. Table 10 reinforces this conjecture. Here, we decompose the improvements in $\Delta R O A_{t+1}^{j}$ (treatment effects in Tables 4 and 8) into three factors: the increase in gross sales, the reduction in expenses, and the reduction in total assets. ${ }^{16}$ If the greater improvements in the profitability of collateralized borrowers (treatment effects) were driven by an increase in the availability of credit to finance new investment projects (Hypothesis 3), then it is likely that, as a result of the new investments, we would observe an increase in gross sales that would contribute to an improvement in ROA. Table 10 shows, however, that the main reason for the improvement in collateralized borrowers' ROA is a reduction in expenses, while the contribution of gross sales to the improvement in collateralized firms' profitability was actually negative. In other word, collateralized borrowers seem to increase their profitability through cost-cutting restructuring. This evidence is contradictory to the availability hypothesis, but is compatible

16 To be precise, the first term of the following equation corresponds to the increase in gross sales, while the second corresponds to the reduction in expenses and the third corresponds to the reduction in total assets. The final cross-factor term is negligible.

$$
\Delta R O A=\frac{\Delta S}{A_{t}}-\frac{\Delta C}{A_{t}}+\left(S_{t}-C_{t}\right) \cdot \Delta\left(\frac{1}{A}\right)+(\Delta S-\Delta C) \cdot \Delta\left(\frac{1}{A}\right)
$$

where $S, C$, and $A$ represent gross sales, expenses, and total assets, respectively. 
with the theory that collateralized borrowers improve their performance through greater managerial effort or by refraining from asset substitution. ${ }^{17}$

(Insert Table 10)

\section{Conclusion}

Focusing on Japanese SMEs, which tend to be dependent on bank loans, we examined the effectiveness of collateral and personal guarantees in improving the ex-post performance of firms, such as their profitability and the probability of falling into financial distress. The examination was based on a unique panel data set of more than 500 Japanese SMEs covering the years 2001-2005.

Employing the matching estimation approach, we found that riskier firms were more likely to pledge collateral and that one year later, their profitability tended to have increased and their riskiness tended to have declined. Most of the estimation results are consistent with the moral hazard hypothesis, according to which risky firms increase their efforts or refrain from asset substitution once they have pledged collateral and as a result end up with improvements in their ex-post performance. The monitoring and availability hypotheses may offer alternative explanations, but we do not find sufficient supportive evidence in our

\footnotetext{
17 Although we do not find supportive evidence for the monitoring hypothesis (Hypothesis 2) in the matching estimations, the results in Table 10 may be consistent with the monitoring hypothesis in that the cost-cutting restructuring of collateralized borrowers may be the result of pressure from their main bank.
} 
empirical analysis. These results become tenuous for personal guarantees.

As far as we know, this is the first empirical analysis on collateralized borrowers' ex-post performance which controls for the possible selection bias in the provision of collateral. There are various possible extensions to this analysis. One is to widen the time window for observing borrowers' ex-post performance. Currently, we only have a one-year window for analysis due to data availability constraints. However, as more data become available over time, we may be able to extend the window to several years. Another possible extension would be to construct the data set in a different manner. In this paper, we limited our sample to borrowers that did not pledge collateral in year $t-1$ and identified the treatment effect by contrasting borrowers pledging collateral in year $t$ with those that did not. As an alternative, we could choose borrowers that pledged collateral in year $t-1$ and identify the effect of collateral by contrasting borrowers ceasing to pledge collateral in year $t$ with those continuing to pledge collateral. This would allow us to address the very interesting question whether newly pledging collateral and ceasing to pledge collateral have symmetric treatment effects. Tackling these issues may reinforce this paper's findings, as well as further expand our understanding of how the provision of collateral attenuates moral hazard and how ceasing to pledge collateral exacerbates it. 


\section{Acknowledgements}

The views expressed in this paper are ours and do not necessarily reflect any of the institutions that we are affiliated with. We would like to thank Hikaru Fukanuma, Masaharu Hanazaki, and Daiji Kawaguchi, as well as seminar participants at the Bank of Japan, the Japanese Economic Association, the Japan Society of Monetary Economics, Nihon University, Osaka University, Research Institute of Capital Formation of the Development Bank of Japan, Tohoku University, Waseda University, and especially members of the Corporate Finance Study Group at RIETI (Research Institute of Economy, Trade, and Industry) for many helpful comments. Any remaining errors are our responsibility.

\section{References}

Becker, S., Ichino, A., 2002. Estimation of Average Treatment Effects Based on Propensity Scores. The Stata Journal 2(4), 358-377.

Berger, A., Udell, G., 1990. Collateral, Loan Quality, and Bank Risk. Journal of Monetary Economics 25(1), 21-42.

Berger, A., Udell, G., 1995. Relationship Lending and Lines of Credit in Small Firm Finance. Journal of Business 68(3), 351-381.

Berger, A., Frame, W. S., and Ioannidou, V., 2009. Tests of Ex Ante versus Ex Post Theories of Collateral Using Private and Public Information. European Banking Center Discussion 
Paper No. 2010-13

Berger, A., Espinosa-Vega, M, Frame, W. S., Miller N., 2006. Why Do Borrowers Pledge Collateral? New Empirical Evidence on the Role of Asymmetric Information. Federal Reserve Bank of Atlanta Working Paper 2006-29a.

Bester, H., 1985. Screening vs. Rationing in Credit Markets with Imperfect Information. American Economic Review 75(4), 850-855.

Besanko, D., Thakor, A., 1987. Collateral and Rationing: Sorting Equilibria in Monopolistic and Competitive Credit Markets. International Economic Review 28(3), 671-689.

Boot, A., Thakor A., Udell G., 1991. Secured Lending and Default Risk: Equilibrium Analysis, Policy Implications and Empirical Results. Economic Journal 101(406), 458-472.

Brick, I., Palia, D., 2007. Evidence of Jointness in the Terms of Relationship Lending. Journal of Financial Intermediation 16(3), 452-476.

Caliendo, M., Kopeinig, S., 2008. Some Practical Guidance for the Implementation of Propensity Score Matching. Journal of Economic Surveys 22(1), 31-72.

Heckman, J., Ichimura, H., Smith, J., Todd, P., 1998. Characterizing Selection Bias Using Experimental Data. Econometrica 66(5), 1017-1098.

Inderst, R., Mueller, H., 2007. A Lender-based Theory of Collateral. Journal of Financial Economics 84(3), 826-859.

Jiménez, G., Salas, V., Saurina, J., 2006. Determinants of Collateral. Journal of Financial 
Economics 81(2), 255-281.

Jiménez, G., Saurina, J., 2004. Collateral, Type of Lender and Relationship Banking as Determinants of Credit Risk. Journal of Banking and Finance 28(9), 2191-2212.

Longhofer, S., Santos, J., 2000. The Importance of Bank Seniority for Relationship Lending. Journal of Financial Intermediation 9(1), 57-89.

Manove, M., Padilla, J., Pagano, M., 2001. Collateral versus Project Screening: A Model of Lazy Banks. RAND Journal of Economics 32(4), 726-744.

Ono, A., Uesugi, I., 2008. Role of Collateral and Personal Guarantees in Relationship Lending: Evidence from Japan’s SME Loan Market. Journal of Money, Credit and Banking 41(5), 935-960.

Orgler, Y., 1970. A Credit Scoring Model for Commercial Loans. Journal of Money, Credit and Banking 2(4), 435-445.

Rajan, R., Winton, A., 1995. Covenants and Collateral as Incentives to Monitor. Journal of Finance 50(4), 1113-1146.

Rosenbaum, P., Rubin, D., 1983. The Central Role of the Propensity Score in Observational Studies for Causal Effects. Biometrika 70(1), 41-55.

Stulz, R., Johnson, H., 1985. An Analysis of Secured Debt. Journal of Financial Economics 14(4), 501-521. 
Table 1: Definitions of Variables
Use of Collateral and Personal Guarantees
COLL $\quad 1$ if the borrower pledges collateral to its main bank, 0 otherwise.
GUAR 1 if the borrower pledges personal guarantees to its main bank,
0 otherwise.
Firm Performance
$R O A$
ICOVER
CAP
Financial Distress
DEFAULT
ROA_NG
ICOVER_SM
CAP_NG
Ratio of pre-tax operating profits to total assets.
Ratio of pre-tax operating profits to interest expenses.
Ratio of capital to total assets.
1 if the borrower defaults, 0 otherwise.
1 if $R O A$ is negative (the borrower is in deficit), 0 otherwise.
1 if ICOVER is less than or equal to one, 0 otherwise.
1 if $C A P$ is negative (the borrower has negative net worth),
0 otherwise.

\section{Lender's Monitoring Activity}

$D O C$

Index variable indicating the frequency of document submissions to the borrower's main bank: 1: annually, 2: semi-annually, 3: quarterly, 4: once every 1-2 months.

\section{Credit Availability}

RES

Index variable indicating the main bank's response to a borrower's loan application: 1: application was rejected or the loan amount was reduced, 2: application was approved, 3: the lender solicited the borrower to increase the loan amount.

FIXED Ratio of fixed tangible assets to total assets.

\section{Borrower Characteristics}

LnEMP Log of the number of employees.

LnLIAB Log of total borrowings.

LONG Ratio of long-term loans (loans with more than 1 year maturity) to total assets.

LAND Ratio of real estate holdings to total assets.

CASH Ratio of cash holdings to total assets.

RATE Ratio on interest expenses to total loan amount.

OWNER $\quad 1$ if a family member of the CEO of the borrower firm is a major shareholder.

\section{Borrower-Lender Relationship}

BANKS Number of banks the borrower firm has transactions with.

LnDURATION Log of the number of years the borrower firm has been transacting with its main bank.

Note: Dummy variables for the initial year, borrower-industry, borrower-region, and the type of main bank are also included in the empirical analysis. 


\section{Table 2: Means for Collateralized and Non-Collateralized Borrowers}

This table presents the means of the main variables used in the probit estimations (Table 3). In order to control for the effects of government credit guarantees on collateral, borrowers that make use of government guarantee programs in any way are omitted from the sample. In the columns under " $C O L L(t-1)=0$," only those firms that do not pledge collateral in year $t-1$ are included. In the column labeled " $C O L L(t)=1$," only firms that do not pledge collateral in year $t-1$ but do pledge collateral in year $t$ are included, while in the column labeled " $C O L L(t)=0$," only firms that pledge collateral neither in year $t-1$ nor in year $t$ are included. The same applies with regard to guarantees in the columns labeled with "GUAR." Definitions of the variables are provided in Table 1 . Standard deviations are in parenthesis.

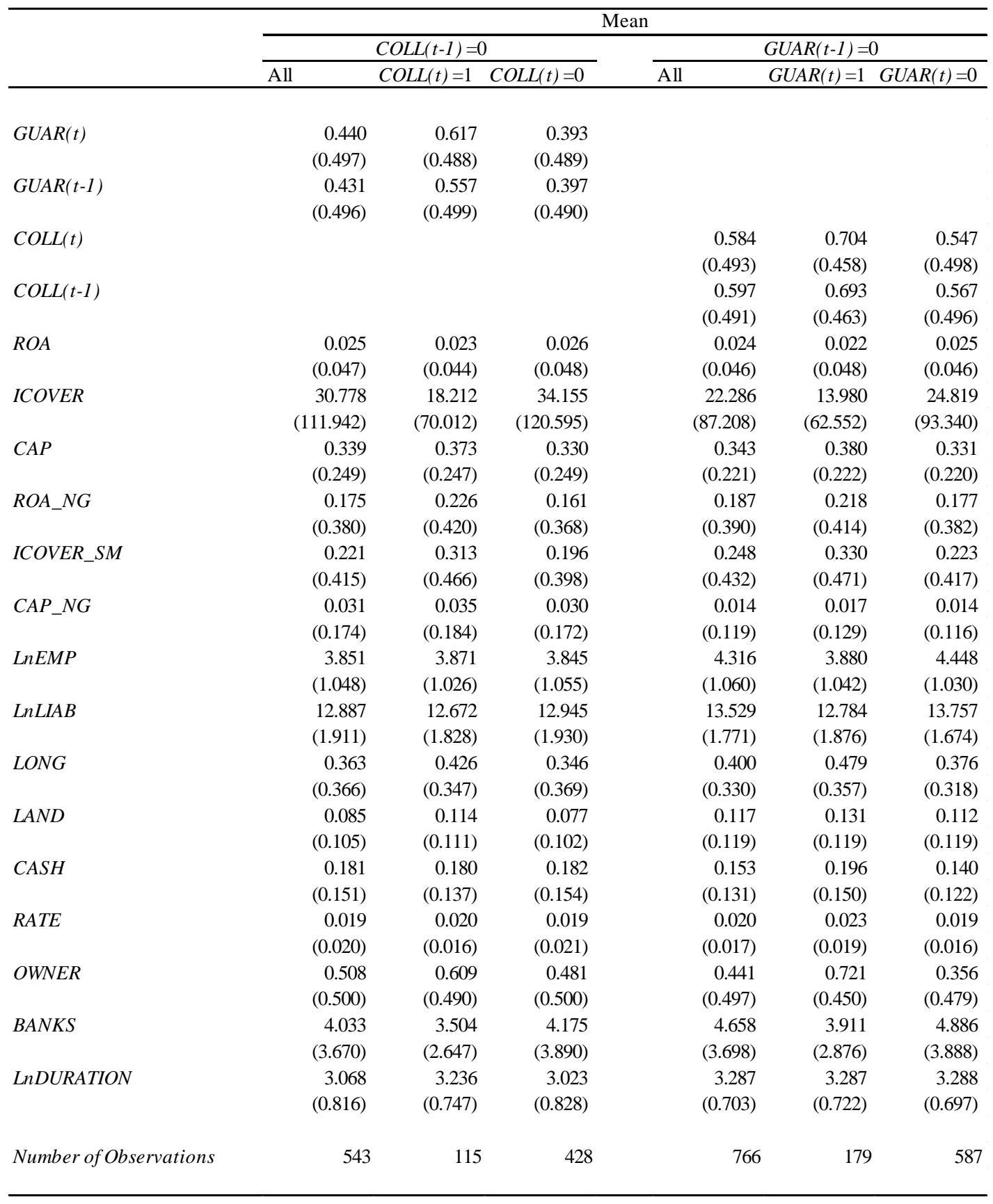




\section{Table 3: Probit Estimation Results on the Use of Collateral and Personal Guarantees}

The sample is the full sample of firms for which summary statistics are shown in Table 2. The first column presents the results of the probit estimation on the use of collateral, while the second column presents those of the probit estimation on the use of personal guarantees. Definitions of the variables are provided in Table 1. Standard errors are in parentheses. ${ }^{* * *},{ }^{* * *}$, *indicate a significance level of 1,5 , and $10 \%$, respectively.

\begin{tabular}{|c|c|c|}
\hline & $\begin{array}{l}\text { Dependent Variable: } \\
\text { COLL }\end{array}$ & $\begin{array}{c}\text { Dependent Variable: } \\
\text { GUAR }\end{array}$ \\
\hline LnEMP & $\begin{array}{c}0.108 \\
(0.087)\end{array}$ & $\begin{array}{l}-0.161^{* *} \\
(0.073)\end{array}$ \\
\hline LnLIAB & $\begin{array}{l}-0.068 \\
(0.065)\end{array}$ & $\begin{array}{l}-0.1400^{* *} \\
(0.059)\end{array}$ \\
\hline CAP & $\begin{array}{l}-0.274 \\
(0.425)\end{array}$ & $\begin{array}{l}-0.640 * \\
(0.358)\end{array}$ \\
\hline$L O N G$ & $\begin{array}{l}0.445 * * \\
(0.193)\end{array}$ & $\begin{array}{c}0.115 \\
(0.184)\end{array}$ \\
\hline LAND & $\begin{array}{l}1.507^{* *} \\
(0.691)\end{array}$ & $\begin{array}{c}0.384 \\
(0.541)\end{array}$ \\
\hline$R O A$ & $\begin{array}{c}3.248 \\
(1.990)\end{array}$ & $\begin{array}{c}2.111 \\
(1.757)\end{array}$ \\
\hline ICOVER & $\begin{array}{l}-0.001 \\
(0.001)\end{array}$ & $\begin{array}{l}-0.001 \\
(0.001)\end{array}$ \\
\hline CASH & $\begin{array}{l}-0.720 \\
(0.556)\end{array}$ & $\begin{array}{c}0.503 \\
(0.498)\end{array}$ \\
\hline RATE & $\begin{array}{c}0.070 \\
(3.778)\end{array}$ & $\begin{array}{l}-3.108 \\
(3.986)\end{array}$ \\
\hline OWNER & $\begin{array}{c}0.009 \\
(0.168)\end{array}$ & $\begin{array}{l}0.7511^{* * *} \\
(0.131)\end{array}$ \\
\hline ROA_NG & $\begin{array}{l}-0.185 \\
(0.332)\end{array}$ & $\begin{array}{l}-0.165 \\
(0.253)\end{array}$ \\
\hline ICOVER_SM & $\begin{array}{l}0.788^{* * *} \\
(0.297)\end{array}$ & $\begin{array}{c}0.339 \\
(0.224)\end{array}$ \\
\hline$C A P \_N G$ & $\begin{array}{c}0.015 \\
(0.428)\end{array}$ & $\begin{array}{c}0.084 \\
(0.503)\end{array}$ \\
\hline BANKS & $\begin{array}{l}-0.003 \\
(0.027)\end{array}$ & $\begin{array}{c}0.010 \\
(0.021)\end{array}$ \\
\hline LnDURATION & $\begin{array}{l}0.186^{* *} \\
(0.092)\end{array}$ & $\begin{array}{l}-0.032 \\
(0.090)\end{array}$ \\
\hline $\operatorname{GUAR}(t)$ & $\begin{array}{l}0.472^{* * *} \\
(0.169)^{*}\end{array}$ & \\
\hline $\operatorname{GUAR}(t-1)$ & $\begin{array}{l}-0.064 \\
(0.169)\end{array}$ & \\
\hline $\operatorname{COLL}(t)$ & & $\begin{array}{l}0.3466^{* *} \\
(0.165)\end{array}$ \\
\hline $\operatorname{COLL}(t-1)$ & & $\begin{array}{c}0.231 \\
(0.167)\end{array}$ \\
\hline Constant & $\begin{array}{c}0.863 \\
(1.396)\end{array}$ & $\begin{array}{l}1.487^{*} \\
(0.898)\end{array}$ \\
\hline Year Dummies & Yes & Yes \\
\hline Industry Dummies & Yes & Yes \\
\hline Dummies for Main Bank Type & Yes & Yes \\
\hline Number of Observations & 543 & 766 \\
\hline Pseudo R-sq & 0.146 & 0.221 \\
\hline Log Likelihood & -239.573 & -324.436 \\
\hline
\end{tabular}


Table 4: Estimated Treatment Effects of Pledging Collateral

This table presents estimated treatment effects of pledging collateral. The column "Treatment" shows the mean of the variables for those firms that pledge collateral in year $t$, while the column "Control" shows the mean of the variables for the matched observations from firms that did not pledge collateral in year $t$. The matched observations have the "closest" propensity scores to a particular treatment observation in the same year. The propensity score is attached to each observation using the probit estimation results from Table 3. The matching algorithm to find the "closest" control observations is 5-nearest matching. Finally, the column "Difference-in-Difference" shows the estimated treatment effects of pledging collateral, which are the differences of yearly differences in the variables of the treatment group and the control group from year $t$ to year $t+1$. The sample is the full sample of firms. Definitions of the variables are provided in Table 1 . Standard errors are in parentheses. ${ }^{* * *},{ }^{* * *},{ }^{*}$ indicate a significance level of 1,5 , and $10 \%$, respectively.

\begin{tabular}{|c|c|c|c|c|}
\hline & \multirow[b]{2}{*}{ Period } & \multicolumn{3}{|c|}{ 5-Nearest Matching } \\
\hline & & Treatment & Control & $\begin{array}{l}\text { Difference } \\
\text { in } \\
\text { Difference }\end{array}$ \\
\hline \multirow[t]{2}{*}{$R O A$} & $t$ & $\begin{array}{c}0.022 \\
(0.005)\end{array}$ & $\begin{array}{c}0.023 \\
(0.002)\end{array}$ & \\
\hline & $t+1$ & $\begin{array}{c}0.032 \\
(0.004)\end{array}$ & $\begin{array}{c}0.021 \\
(0.002)\end{array}$ & $\begin{array}{c}0.0122^{* *} \\
(0.005)\end{array}$ \\
\hline \multirow[t]{2}{*}{ CAP } & $t$ & $\begin{array}{c}0.380 \\
(0.025)\end{array}$ & $\begin{array}{c}0.373 \\
(0.011)\end{array}$ & \\
\hline & $t+1$ & $\begin{array}{c}0.396 \\
(0.024)\end{array}$ & $\begin{array}{c}0.370 \\
(0.011)\end{array}$ & $\begin{array}{l}0.019 \text { ** } \\
(0.008)\end{array}$ \\
\hline \multirow[t]{2}{*}{ ICOVER } & $t$ & $\begin{array}{l}10.857 \\
(3.360)\end{array}$ & $\begin{array}{l}20.267 \\
(4.232)\end{array}$ & \\
\hline & $t+1$ & $\begin{array}{l}24.943 \\
(5.200)\end{array}$ & $\begin{array}{l}27.787 \\
(6.542)\end{array}$ & $\begin{array}{c}6.567 \\
(7.450)\end{array}$ \\
\hline \multirow[t]{2}{*}{ RATE } & $t$ & $\begin{array}{c}0.018 \\
(0.001)\end{array}$ & $\begin{array}{c}0.024 \\
(0.002)\end{array}$ & \\
\hline & $t+1$ & $\begin{array}{c}0.020 \\
(0.002)\end{array}$ & $\begin{array}{c}0.018 \\
(0.001)\end{array}$ & $\begin{array}{l}0.007^{* * *} \\
(0.002)\end{array}$ \\
\hline \multirow[t]{2}{*}{$p(D E F A U L T)$} & $t$ & $\begin{array}{c}0.000 \\
(0.000)\end{array}$ & $\begin{array}{c}0.000 \\
(0.000)\end{array}$ & \\
\hline & $t+1$ & $\begin{array}{c}0.000 \\
(0.000)\end{array}$ & $\begin{array}{c}0.006 \\
(0.003)\end{array}$ & $\begin{array}{l}-0.006 * \\
(0.003)\end{array}$ \\
\hline \multirow[t]{2}{*}{$p\left(C A P \_N G\right)$} & $t$ & $\begin{array}{c}0.021 \\
(0.015)\end{array}$ & $\begin{array}{c}0.042 \\
(0.009)\end{array}$ & \\
\hline & $t+1$ & $\begin{array}{c}0.000 \\
(0.000)\end{array}$ & $\begin{array}{c}0.051 \\
(0.009)\end{array}$ & $\begin{array}{l}-0.029 * \\
(0.015)\end{array}$ \\
\hline \multirow[t]{2}{*}{$p\left(I C O V E R \_S M\right)$} & $t$ & $\begin{array}{c}0.299 \\
(0.049)\end{array}$ & $\begin{array}{c}0.280 \\
(0.024)\end{array}$ & \\
\hline & $t+1$ & $\begin{array}{c}0.138 \\
(0.037)\end{array}$ & $\begin{array}{c}0.290 \\
(0.018)\end{array}$ & $\begin{array}{l}-0.170^{* * *} \\
(0.051)\end{array}$ \\
\hline \multirow[t]{2}{*}{$p\left(R O A \_N G\right)$} & $t$ & $\begin{array}{c}0.221 \\
(0.043)\end{array}$ & $\begin{array}{c}0.213 \\
(0.021)\end{array}$ & \\
\hline & $t+1$ & $\begin{array}{c}0.116 \\
(0.033)\end{array}$ & $\begin{array}{c}0.227 \\
(0.016)\end{array}$ & $\begin{array}{l}-0.120 * * \\
(0.049)\end{array}$ \\
\hline \multirow[t]{2}{*}{$D O C$} & $t-1$ & $\begin{array}{c}1.569 \\
(0.095)\end{array}$ & $\begin{array}{c}1.502 \\
(0.043)\end{array}$ & \\
\hline & $t$ & $\begin{array}{c}1.585 \\
(0.105)\end{array}$ & $\begin{array}{c}1.575 \\
(0.046)\end{array}$ & $\begin{array}{l}-0.058 \\
(0.103)\end{array}$ \\
\hline \multirow[t]{2}{*}{ RES } & $t-1$ & $\begin{array}{c}2.479 \\
(0.079)\end{array}$ & $\begin{array}{c}2.442 \\
(0.030)\end{array}$ & \\
\hline & $t$ & $\begin{array}{c}2.479 \\
(0.079)\end{array}$ & $\begin{array}{c}2.383 \\
(0.025)\end{array}$ & $\begin{array}{c}0.058 \\
(0.093)\end{array}$ \\
\hline \multirow[t]{2}{*}{ FIXED } & $t-1$ & $\begin{array}{c}0.269 \\
(0.018)\end{array}$ & $\begin{array}{c}0.300 \\
(0.012)\end{array}$ & \\
\hline & $t$ & $\begin{array}{c}0.280 \\
(0.018)\end{array}$ & $\begin{array}{c}0.309 \\
(0.012)\end{array}$ & $\begin{array}{c}0.002 \\
(0.007)\end{array}$ \\
\hline
\end{tabular}




\section{Table 5: Estimated Treatment Effects of Pledging Personal Guarantees}

This table presents estimated treatment effects of pledging personal guarantees. The column "Treatment" shows the mean of the variables for those firms that pledge personal guarantees in year $t$, while the column "Control" shows the mean of the variables for the matched observations from firms that did not pledge personal guarantees in year $t$. The matched observations have the "closest" propensity scores to a particular treatment observation in the same year. The propensity score is attached to each observation using the probit estimation results from Table 3. The matching algorithm to find the "closest" control observations is 5-nearest matching. Finally, the column "Difference-in-Difference" shows the estimated treatment effects of pledging personal guarantees, which are the differences of yearly differences in the variables of the treatment group and the control group from year $t$ to year $t+1$. The sample is the full sample of firms of the baseline estimation. Definitions of the variables are shown in Table 1 . Standard errors are in parentheses. ${ }^{* * *},{ }^{* *},{ }^{*}$ indicate a significance level of 1,5 , and $10 \%$, respectively.

\begin{tabular}{|c|c|c|c|c|}
\hline & \multirow[b]{2}{*}{ Period } & \multicolumn{3}{|c|}{ 5-Nearest Matching } \\
\hline & & Treatment & Control & $\begin{array}{l}\text { Difference } \\
\text { in } \\
\text { Difference }\end{array}$ \\
\hline \multirow[t]{2}{*}{$R O A$} & $t$ & $\begin{array}{c}0.021 \\
(0.004)\end{array}$ & $\begin{array}{c}0.029 \\
(0.001)\end{array}$ & \\
\hline & $t+1$ & $\begin{array}{c}0.024 \\
(0.003)\end{array}$ & $\begin{array}{c}0.028 \\
(0.002)\end{array}$ & $\begin{array}{c}0.004 \\
(0.004)\end{array}$ \\
\hline \multirow[t]{2}{*}{ CAP } & $t$ & $\begin{array}{c}0.378 \\
(0.017)\end{array}$ & $\begin{array}{c}0.411 \\
(0.008)\end{array}$ & \\
\hline & $t+1$ & $\begin{array}{c}0.393 \\
(0.018)\end{array}$ & $\begin{array}{c}0.425 \\
(0.009)\end{array}$ & $\begin{array}{c}0.001 \\
(0.005)\end{array}$ \\
\hline \multirow[t]{2}{*}{ ICOVER } & $t$ & $\begin{array}{l}15.438 \\
(5.134)\end{array}$ & $\begin{array}{l}21.110 \\
(2.569)\end{array}$ & \\
\hline & $t+1$ & $\begin{array}{l}16.687 \\
(3.678)\end{array}$ & $\begin{array}{l}33.787 \\
(4.862)\end{array}$ & $\begin{array}{c}-11.428 \\
(6.523)\end{array}$ \\
\hline \multirow[t]{2}{*}{ RATE } & $t$ & $\begin{array}{c}0.021 \\
(0.001)\end{array}$ & $\begin{array}{c}0.022 \\
(0.001)\end{array}$ & \\
\hline & $t+1$ & $\begin{array}{c}0.020 \\
(0.001)\end{array}$ & $\begin{array}{c}0.022 \\
(0.001)\end{array}$ & $\begin{array}{c}0.000 \\
(0.001)\end{array}$ \\
\hline \multirow[t]{2}{*}{$p(D E F A U L T)$} & $t$ & $\begin{array}{c}0.000 \\
(0.000)\end{array}$ & $\begin{array}{c}0.000 \\
(0.000)\end{array}$ & \\
\hline & $t+1$ & $\begin{array}{c}0.000 \\
(0.000)\end{array}$ & $\begin{array}{c}0.000 \\
(0.000)\end{array}$ & $\begin{array}{c}0.000 \\
(0.000)\end{array}$ \\
\hline \multirow[t]{2}{*}{$p\left(C A P \_N G\right)$} & $t$ & $\begin{array}{c}0.012 \\
(0.009)\end{array}$ & $\begin{array}{c}0.006 \\
(0.003)\end{array}$ & \\
\hline & $t+1$ & $\begin{array}{c}0.006 \\
(0.006)\end{array}$ & $\begin{array}{c}0.006 \\
(0.003)\end{array}$ & $\begin{array}{l}-0.006 \\
(0.007)\end{array}$ \\
\hline \multirow[t]{2}{*}{$p\left(I C O V E R \_S M\right)$} & $t$ & $\begin{array}{c}0.317 \\
(0.037)\end{array}$ & $\begin{array}{c}0.266 \\
(0.016)\end{array}$ & \\
\hline & $t+1$ & $\begin{array}{c}0.273 \\
(0.035)\end{array}$ & $\begin{array}{c}0.221 \\
(0.015)\end{array}$ & $\begin{array}{c}0.001 \\
(0.038)\end{array}$ \\
\hline \multirow[t]{2}{*}{$p\left(R O A \_N G\right)$} & $t$ & $\begin{array}{c}0.210 \\
(0.032)\end{array}$ & $\begin{array}{c}0.178 \\
(0.012)\end{array}$ & \\
\hline & $t+1$ & $\begin{array}{c}0.222 \\
(0.033)\end{array}$ & $\begin{array}{c}0.214 \\
(0.016)\end{array}$ & $\begin{array}{l}-0.023 \\
(0.039)\end{array}$ \\
\hline \multirow[t]{2}{*}{$D O C$} & $t-1$ & $\begin{array}{c}1.664 \\
(0.085)\end{array}$ & $\begin{array}{c}1.595 \\
(0.038)\end{array}$ & \\
\hline & $t$ & $\begin{array}{c}1.794 \\
(0.085)\end{array}$ & $\begin{array}{c}1.682 \\
(0.043)\end{array}$ & $\begin{array}{c}0.043 \\
(0.072)\end{array}$ \\
\hline \multirow[t]{2}{*}{ RES } & $t-1$ & $\begin{array}{c}2.435 \\
(0.067)\end{array}$ & $\begin{array}{c}2.426 \\
(0.022)\end{array}$ & \\
\hline & $t$ & $\begin{array}{c}2.377 \\
(0.066)\end{array}$ & $\begin{array}{c}2.501 \\
(0.027)\end{array}$ & $\begin{array}{l}-0.133 * \\
(0.077)\end{array}$ \\
\hline \multirow[t]{2}{*}{ FIXED } & $t-1$ & $\begin{array}{c}0.308 \\
(0.015)\end{array}$ & $\begin{array}{c}0.281 \\
(0.007)\end{array}$ & \\
\hline & $t$ & $\begin{array}{c}0.311 \\
(0.015)\end{array}$ & $\begin{array}{c}0.288 \\
(0.007)\end{array}$ & $\begin{array}{l}-0.004 \\
(0.004)\end{array}$ \\
\hline
\end{tabular}


Table 6: Probit Estimation Results on the Use of Collateral and Personal Guarantees (Including Firms that Partially Relied on Government Guarantees)

The sample includes firms that partially relied on government guarantees. Summary statistics for this sample are provided in the Appendix Table. The first column presents the results of the probit estimation on the use of collateral, while the second column presents those of the probit estimation on the use of personal guarantees. Definitions of the variables are provided in Table 1. Standard errors are in parentheses. ${ }^{* * *},{ }^{* *},{ }^{*}$ indicate a significance level of 1,5 , and $10 \%$, respectively.

\begin{tabular}{|c|c|c|}
\hline & $\begin{array}{l}\text { Dependent Variable: } \\
\text { COLL }\end{array}$ & $\begin{array}{c}\text { Dependent Variable: } \\
\text { GUAR }\end{array}$ \\
\hline LnEMP & $\begin{array}{c}0.097 \\
(0.077)\end{array}$ & $\begin{array}{l}-0.142^{* *} \\
(0.067)\end{array}$ \\
\hline LnLIAB & $\begin{array}{l}-0.032 \\
(0.058)\end{array}$ & $\begin{array}{l}-0.105^{* *} \\
(0.053)\end{array}$ \\
\hline CAP & $\begin{array}{l}-0.256 \\
(0.374)\end{array}$ & $\begin{array}{l}-0.674^{* *} \\
(0.325)\end{array}$ \\
\hline LONG & $\begin{array}{l}0.3933^{* *} \\
(0.174)\end{array}$ & $\begin{array}{c}0.131 \\
(0.169)\end{array}$ \\
\hline LAND & $\begin{array}{l}1.274^{* *} \\
(0.599)\end{array}$ & $\begin{array}{c}0.750 \\
(0.485)\end{array}$ \\
\hline$R O A$ & $\begin{array}{l}3.7399^{* *} \\
(1.667)\end{array}$ & $\begin{array}{c}1.421 \\
(1.605)\end{array}$ \\
\hline ICOVER & $\begin{array}{l}-0.001 \\
(0.001)\end{array}$ & $\begin{array}{l}-0.001 \\
(0.001)\end{array}$ \\
\hline CASH & $\begin{array}{l}-0.349 \\
(0.459)\end{array}$ & $\begin{array}{c}0.507 \\
(0.452)\end{array}$ \\
\hline RATE & $\begin{array}{l}-2.598 \\
(3.118)\end{array}$ & $\begin{array}{c}0.620 \\
(3.147)\end{array}$ \\
\hline OWNER & $\begin{array}{c}0.024 \\
(0.143)\end{array}$ & $\begin{array}{l}0.703^{* * *} \\
(0.122)\end{array}$ \\
\hline$R O A \_N G$ & $\begin{array}{c}0.252 \\
(0.262)\end{array}$ & $\begin{array}{l}-0.210 \\
(0.219)\end{array}$ \\
\hline ICOVER_SM & $\begin{array}{c}0.374 \\
(0.231)\end{array}$ & $\begin{array}{c}0.312 \\
(0.192)\end{array}$ \\
\hline CAP_NG & $\begin{array}{c}0.144 \\
(0.366)\end{array}$ & $\begin{array}{c}0.263 \\
(0.430)\end{array}$ \\
\hline BANKS & $\begin{array}{l}-0.010 \\
(0.023)\end{array}$ & $\begin{array}{l}-0.002 \\
(0.019)\end{array}$ \\
\hline LnDURATION & $\begin{array}{l}0.232^{* * *} \\
(0.079)\end{array}$ & $\begin{array}{c}0.028 \\
(0.084)\end{array}$ \\
\hline $\operatorname{GUAR}(t)$ & $\begin{array}{l}0.427^{* * *} \\
(0.148)\end{array}$ & \\
\hline $\operatorname{GUAR}(t-1)$ & $\begin{array}{l}-0.081 \\
(0.145)\end{array}$ & \\
\hline $\operatorname{COLL}(t)$ & & $\begin{array}{l}0.387^{* * *} \\
(0.147)^{2}\end{array}$ \\
\hline $\operatorname{COLL}(t-1)$ & & $\begin{array}{c}0.093 \\
(0.144)\end{array}$ \\
\hline $\operatorname{GOVGUAR}(t)$ & $\begin{array}{l}1.106^{* * *} \\
(0.193)^{*}\end{array}$ & $\begin{array}{l}0.939^{* * *} \\
(0.190)\end{array}$ \\
\hline $\operatorname{GOVGUAR}(t-1)$ & $\begin{array}{l}0.350 \\
(0.207)\end{array}$ & $\begin{array}{c}0.143 \\
(0.208)\end{array}$ \\
\hline Constant & $\begin{array}{l}-1.840 \\
(0.768)\end{array}$ & $\begin{array}{c}0.129 \\
(0.734)\end{array}$ \\
\hline Year Dummies & Yes & Yes \\
\hline Industry Dummies & Yes & Yes \\
\hline Dummies for Main Bank Type & Yes & Yes \\
\hline Number of Observations & 701 & 928 \\
\hline Pseudo R-sq & 0.262 & 0.323 \\
\hline Log Likelihood & -317.625 & -399.284 \\
\hline
\end{tabular}


Table 7: Estimated Treatment Effects of Pledging Collateral and Personal Guarantees (Including Firms that Partially Relied on Government Guarantees)

This table presents estimated treatment effects of pledging collateral (columns under "COLL") and personal guarantees (columns under "GUAR"). The column "Treatment" shows the mean of the variables for those firms that pledge collateral/personal guarantees in year $t$, while the column "Control" shows the mean of the variables for the matched observations from firms that did not pledge collateral/personal guarantees in year $t$. The matched observations have the "closest" propensity scores to a particular treatment observation in the same year. The propensity score is attached to each observation using the probit estimation results from Table 6. The matching algorithm to find the "closest" control observations is 5-nearest matching. Finally, the column "Difference-in-Difference" shows the estimated treatment effects of pledging collateral/personal guarantees, which are the differences of yearly differences in the variables of the treatment group and the control group from year $t$ to year $t+1$. The sample is the enlarged sample of firms including those that partially relied on government guarantees. Definitions of the variables are provided in Table 1. Standard errors are in parentheses. ${ }^{* * * *}$, ${ }^{* *},{ }^{*}$ indicate a significance level of 1,5 , and $10 \%$, respectively.

\begin{tabular}{|c|c|c|c|c|c|c|c|}
\hline & \multirow[b]{2}{*}{ Period } & \multicolumn{3}{|c|}{ COLL } & \multicolumn{3}{|c|}{ GUAR } \\
\hline & & Treatment & Control & $\begin{array}{l}\text { Difference } \\
\text { in } \\
\text { Difference }\end{array}$ & Treatment & Control & $\begin{array}{l}\text { Difference } \\
\text { in } \\
\text { Difference }\end{array}$ \\
\hline \multirow[t]{2}{*}{$R O A$} & $t$ & $\begin{array}{c}0.019 \\
(0.004)\end{array}$ & $\begin{array}{c}0.020 \\
(0.001)\end{array}$ & & $\begin{array}{c}0.018 \\
(0.003)\end{array}$ & $\begin{array}{c}0.025 \\
(0.001)\end{array}$ & \\
\hline & $t+1$ & $\begin{array}{c}0.027 \\
(0.004)\end{array}$ & $\begin{array}{c}0.019 \\
(0.002)\end{array}$ & $\begin{array}{l}0.008 \\
(0.004)\end{array}$ & $\begin{array}{c}0.020 \\
(0.003)\end{array}$ & $\begin{array}{c}0.025 \\
(0.002)\end{array}$ & $\begin{array}{c}0.001 \\
(0.003)\end{array}$ \\
\hline \multirow[t]{2}{*}{$C A P$} & $t$ & $\begin{array}{c}0.334 \\
(0.017)\end{array}$ & $\begin{array}{c}0.328 \\
(0.009)\end{array}$ & & $\begin{array}{c}0.339 \\
(0.014)\end{array}$ & $\begin{array}{c}0.359 \\
(0.007)\end{array}$ & \\
\hline & $t+1$ & $\begin{array}{c}0.340 \\
(0.017)\end{array}$ & $\begin{array}{c}0.342 \\
(0.009)\end{array}$ & $\begin{array}{l}-0.008 \\
(0.006)\end{array}$ & $\begin{array}{c}0.350 \\
(0.014)\end{array}$ & $\begin{array}{c}0.377 \\
(0.007)\end{array}$ & $\begin{array}{l}-0.006 \\
(0.004)\end{array}$ \\
\hline \multirow[t]{2}{*}{ ICOVER } & $t$ & $\begin{array}{c}7.161 \\
(2.062)\end{array}$ & $\begin{array}{l}12.938 \\
(1.957)\end{array}$ & & $\begin{array}{l}10.314 \\
(3.366)\end{array}$ & $\begin{array}{l}12.652 \\
(1.500)\end{array}$ & \\
\hline & $t+1$ & $\begin{array}{l}15.064 \\
(3.204)\end{array}$ & $\begin{array}{l}16.131 \\
(2.425)\end{array}$ & $\begin{array}{c}4.710 \\
(3.664)\end{array}$ & $\begin{array}{l}11.790 \\
(2.500)\end{array}$ & $\begin{array}{l}19.364 \\
(3.384)\end{array}$ & $\begin{array}{l}-5.236 \\
(4.008)\end{array}$ \\
\hline \multirow[t]{2}{*}{ RATE } & $t$ & $\begin{array}{c}0.021 \\
(0.001)\end{array}$ & $\begin{array}{c}0.019 \\
(0.001)\end{array}$ & & $\begin{array}{c}0.022 \\
(0.001)\end{array}$ & $\begin{array}{c}0.023 \\
(0.000)\end{array}$ & \\
\hline & $t+1$ & $\begin{array}{c}0.022 \\
(0.001)\end{array}$ & $\begin{array}{c}0.018 \\
(0.000)\end{array}$ & $\begin{array}{l}0.0033^{* *} \\
(0.001)\end{array}$ & $\begin{array}{c}0.021 \\
(0.001)\end{array}$ & $\begin{array}{c}0.024 \\
(0.000)\end{array}$ & $\begin{array}{l}-0.0022^{* *} \\
(0.001)\end{array}$ \\
\hline \multirow[t]{2}{*}{$p(D E F A U L T)$} & $t$ & $\begin{array}{c}0.000 \\
(0.000)\end{array}$ & $\begin{array}{c}0.000 \\
(0.000)\end{array}$ & & $\begin{array}{c}0.000 \\
(0.000)\end{array}$ & $\begin{array}{c}0.000 \\
(0.000)\end{array}$ & \\
\hline & $t+1$ & $\begin{array}{c}0.000 \\
(0.000)\end{array}$ & $\begin{array}{c}0.001 \\
(0.001)\end{array}$ & $\begin{array}{l}-0.001 \\
(0.001)\end{array}$ & $\begin{array}{r}0.004 \\
(0.004)\end{array}$ & $\begin{array}{c}0.001 \\
(0.001)\end{array}$ & $\begin{array}{c}0.003 \\
(0.004)\end{array}$ \\
\hline \multirow[t]{2}{*}{$p\left(C A P \_N G\right)$} & $t$ & $\begin{array}{c}0.025 \\
(0.012)\end{array}$ & $\begin{array}{c}0.038 \\
(0.006)\end{array}$ & & $\begin{array}{c}0.020 \\
(0.009)\end{array}$ & $\begin{array}{c}0.007 \\
(0.002)\end{array}$ & \\
\hline & $t+1$ & $\begin{array}{c}0.012 \\
(0.009)\end{array}$ & $\begin{array}{c}0.041 \\
(0.006)\end{array}$ & $\begin{array}{l}-0.015 * \\
(0.009)\end{array}$ & $\begin{array}{c}0.012 \\
(0.007)\end{array}$ & $\begin{array}{c}0.006 \\
(0.002)\end{array}$ & $\begin{array}{l}-0.007 \\
(0.006)\end{array}$ \\
\hline \multirow[t]{2}{*}{$p\left(I C O V E R \_S M\right)$} & $t$ & $\begin{array}{c}0.346 \\
(0.039)\end{array}$ & $\begin{array}{c}0.316 \\
(0.017)\end{array}$ & & $\begin{array}{c}0.356 \\
(0.030)\end{array}$ & $\begin{array}{c}0.351 \\
(0.015)\end{array}$ & \\
\hline & $t+1$ & $\begin{array}{r}0.203 \\
(0.033)\end{array}$ & $\begin{array}{c}0.241 \\
(0.017)\end{array}$ & $\begin{array}{l}-0.068 \\
(0.042)\end{array}$ & $\begin{array}{c}0.312 \\
(0.029)\end{array}$ & $\begin{array}{r}0.215 \\
(0.011)\end{array}$ & $\begin{array}{l}0.092^{* * * *} \\
(0.033)\end{array}$ \\
\hline \multirow[t]{2}{*}{$p\left(R O A \_N G\right)$} & $t$ & $\begin{array}{c}0.263 \\
(0.035)\end{array}$ & $\begin{array}{c}0.223 \\
(0.012)\end{array}$ & & $\begin{array}{c}0.228 \\
(0.026)\end{array}$ & $\begin{array}{c}0.234 \\
(0.010)\end{array}$ & \\
\hline & $t+1$ & $\begin{array}{c}0.138 \\
(0.027)\end{array}$ & $\begin{array}{c}0.194 \\
(0.016)\end{array}$ & $\begin{array}{l}-0.0966^{* * *} \\
(0.036)\end{array}$ & $\begin{array}{r}0.248 \\
(0.027)\end{array}$ & $\begin{array}{c}0.190 \\
(0.011)\end{array}$ & $\begin{array}{l}0.0644^{* *} \\
(0.031)\end{array}$ \\
\hline \multirow[t]{2}{*}{$D O C$} & $t-1$ & $\begin{array}{c}1.625 \\
(0.078)\end{array}$ & $\begin{array}{c}1.520 \\
(0.031)\end{array}$ & & $\begin{array}{c}1.764 \\
(0.072)\end{array}$ & $\begin{array}{c}1.619 \\
(0.025)\end{array}$ & \\
\hline & $t$ & $\begin{array}{r}1.725 \\
(0.087)\end{array}$ & $\begin{array}{c}1.498 \\
(0.034)\end{array}$ & $\begin{array}{c}0.122 \\
(0.082)\end{array}$ & $\begin{array}{c}1.913 \\
(0.074)\end{array}$ & $\begin{array}{c}1.774 \\
(0.024)\end{array}$ & $\begin{array}{l}-0.006 \\
(0.060)\end{array}$ \\
\hline \multirow[t]{2}{*}{ RES } & $t-1$ & $\begin{array}{c}2.432 \\
(0.061)\end{array}$ & $\begin{array}{c}2.375 \\
(0.029)\end{array}$ & & $\begin{array}{c}2.372 \\
(0.049)\end{array}$ & $\begin{array}{c}2.369 \\
(0.020)\end{array}$ & \\
\hline & $t$ & $\begin{array}{c}2.469 \\
(0.061)\end{array}$ & $\begin{array}{r}2.353 \\
(0.028)\end{array}$ & $\begin{array}{c}0.059 \\
(0.077)\end{array}$ & $\begin{array}{c}2.339 \\
(0.049)\end{array}$ & $\begin{array}{c}2.418 \\
(0.023)\end{array}$ & $\begin{array}{l}-0.083 \\
(0.055)\end{array}$ \\
\hline \multirow[t]{2}{*}{ FIXED } & $t-1$ & $\begin{array}{c}0.231 \\
(0.014)\end{array}$ & $\begin{array}{c}0.277 \\
(0.008)\end{array}$ & & $\begin{array}{c}0.297 \\
(0.012)\end{array}$ & $\begin{array}{c}0.278 \\
(0.005)\end{array}$ & \\
\hline & $t$ & $\begin{array}{c}0.241 \\
(0.014)\end{array}$ & $\begin{array}{c}0.281 \\
(0.008)\end{array}$ & $\begin{array}{c}0.006 \\
(0.005)\end{array}$ & $\begin{array}{c}0.302 \\
(0.012)\end{array}$ & $\begin{array}{c}0.283 \\
(0.005)\end{array}$ & $\begin{array}{c}0.000 \\
(0.003)\end{array}$ \\
\hline
\end{tabular}


Table 8: Estimated Treatment Effects of Pledging Collateral (Different Matching Algorithms)

This table presents estimated treatment effects of pledging collateral using different matching algorithms (10-nearest matching, kernel matching, and radius matching). The column "Treatment" shows the mean of the variables for those firms that pledge collateral in year $t$, while the column "Control" shows the mean of the variables for the matched observations from firms that did not pledge collateral in year $t$. The matched observations have the "closest" propensity scores to a particular treatment observation in the same year. The propensity score is attached to each observation using the probit estimation results from Table 3. The matching algorithm to find the "closest" control observations - 10-nearest matching, kernel matching, or radius matching - is shown in the first row of the table. Finally, the column "Difference-in-Difference" shows the estimated treatment effects of pledging collateral, which are the differences of yearly differences in the variables of the treatment group and the control group from year $t$ to year $t+1$. The sample is the full sample of firms. Definitions of the variables are provided in Table 1 . Standard errors are in parentheses. ${ }^{* * *},{ }^{* *},{ }^{*}$ indicate a significance level of 1,5 , and $10 \%$, respectively.

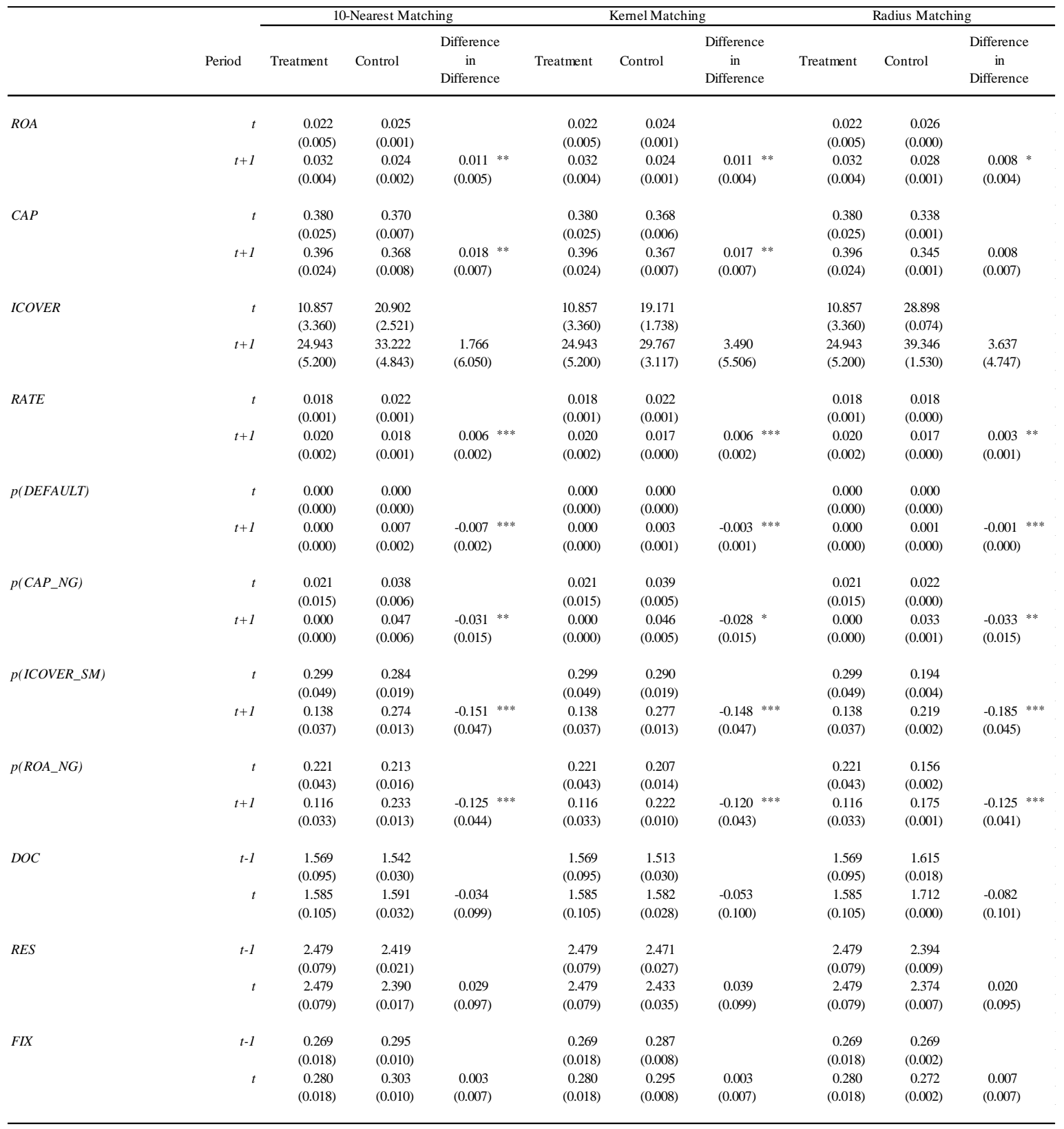


Table 9: Estimated Treatment Effects of Pledging Personal Guarantees (Different Matching Algorithms)

This table presents estimated treatment effects of pledging personal guarantees using different matching algorithms (10-nearest matching, kernel matching, and radius matching). The column "Treatment" shows the mean of the variables for those firms that pledge collateral in year $t$, while the column "Control" shows the mean of the variables for the matched observations from firms that did not pledge personal guarantees in year $t$. The matched observations have the "closest" propensity scores to a particular treatment observation in the same year. The propensity score is attached to each observation using the probit estimation results from Table 3. The matching algorithm to find the "closest" control observations 10-nearest matching, kernel matching, or radius matching - is shown in the first row of the table. Finally, the column "Difference-in-Difference" shows the estimated treatment effects of pledging personal guarantees, which are the differences of yearly differences in the variables of the treatment group and the control group from year $t$ to year $t+1$. The sample is the full sample of firms. Definitions of the variables are provided in Table 1. Standard errors are in parentheses. ${ }^{* * *},{ }^{* * *},{ }^{*}$ indicate a significance level of 1,5 , and $10 \%$, respectively.

\begin{tabular}{|c|c|c|c|c|c|c|c|c|c|c|}
\hline & \multirow[b]{2}{*}{ Period } & \multicolumn{3}{|c|}{ 10-Nearest Matching } & \multicolumn{3}{|c|}{ Kernel Matching } & \multicolumn{3}{|c|}{ Radius Matching } \\
\hline & & Treatment & Control & $\begin{array}{c}\text { Difference } \\
\text { in } \\
\text { Difference }\end{array}$ & Treatment & Control & $\begin{array}{c}\text { Difference } \\
\text { in } \\
\text { Difference }\end{array}$ & Treatment & Control & $\begin{array}{c}\text { Difference } \\
\text { in } \\
\text { Difference }\end{array}$ \\
\hline \multirow[t]{2}{*}{$R O A$} & $t$ & $\begin{array}{c}0.021 \\
(0.004)\end{array}$ & $\begin{array}{c}0.026 \\
(0.001)\end{array}$ & & $\begin{array}{c}0.021 \\
(0.004)\end{array}$ & $\begin{array}{c}0.026 \\
(0.001)\end{array}$ & & $\begin{array}{c}0.021 \\
(0.004)\end{array}$ & $\begin{array}{c}0.024 \\
(0.000)\end{array}$ & \\
\hline & $t+1$ & $\begin{array}{c}0.024 \\
(0.003)\end{array}$ & $\begin{array}{c}0.026 \\
(0.001)\end{array}$ & $\begin{array}{c}0.003 \\
(0.003)\end{array}$ & $\begin{array}{c}0.024 \\
(0.003)\end{array}$ & $\begin{array}{c}0.026 \\
(0.002)\end{array}$ & $\begin{array}{c}0.003 \\
(0.004)\end{array}$ & $\begin{array}{c}0.024 \\
(0.003)\end{array}$ & $\begin{array}{c}0.029 \\
(0.001)\end{array}$ & $\begin{array}{l}-0.002 \\
(0.003)\end{array}$ \\
\hline CAP & $t+1$ & $\begin{array}{c}0.393 \\
(0.018)\end{array}$ & $\begin{array}{r}0.425 \\
(0.007)\end{array}$ & $\begin{array}{c}0.001 \\
(0.005)\end{array}$ & $\begin{array}{c}0.393 \\
(0.018)\end{array}$ & $\begin{array}{c}0.412 \\
(0.007)\end{array}$ & $\begin{array}{l}-0.004 \\
(0.006)\end{array}$ & $\begin{array}{c}0.393 \\
(0.018)\end{array}$ & $\begin{array}{c}0.348 \\
(0.001)\end{array}$ & $\begin{array}{c}0.006 \\
(0.005)\end{array}$ \\
\hline ICOVER & $t$ & $\begin{array}{l}15.438 \\
(5.134)\end{array}$ & $\begin{array}{l}21.310 \\
(1.554)\end{array}$ & & $\begin{array}{l}15.438 \\
(5.134)\end{array}$ & $\begin{array}{l}19.858 \\
(2.035)\end{array}$ & & $\begin{array}{l}15.438 \\
(5.134)\end{array}$ & $\begin{array}{l}22.446 \\
(0.255)\end{array}$ & \\
\hline RATE & $t+1$ & $\begin{array}{c}0.020 \\
(0.001)\end{array}$ & $\begin{array}{c}0.021 \\
(0.000)\end{array}$ & $\begin{array}{c}0.000 \\
(0.001)\end{array}$ & $\begin{array}{c}0.020 \\
(0.001)\end{array}$ & $\begin{array}{c}0.022 \\
(0.000)\end{array}$ & $\begin{array}{l}-0.001 \\
(0.001)\end{array}$ & $\begin{array}{c}0.020 \\
(0.001)\end{array}$ & $\begin{array}{c}0.018 \\
(0.000)\end{array}$ & $\begin{array}{l}-0.001 \\
(0.001)\end{array}$ \\
\hline \multirow[t]{2}{*}{$p(D E F A U L T)$} & $t$ & $\begin{array}{c}0.000 \\
(0.000)\end{array}$ & $\begin{array}{c}0.000 \\
(0.000)\end{array}$ & & $\begin{array}{c}0.000 \\
(0.000)\end{array}$ & $\begin{array}{c}0.000 \\
(0.000)\end{array}$ & & $\begin{array}{c}0.000 \\
(0.000)\end{array}$ & $\begin{array}{c}0.000 \\
(0.000)\end{array}$ & \\
\hline & $t+1$ & $\begin{array}{c}0.000 \\
(0.000)\end{array}$ & $\begin{array}{c}0.000 \\
(0.000)\end{array}$ & $\begin{array}{c}0.000 \\
(0.000)\end{array}$ & $\begin{array}{c}0.000 \\
(0.000)\end{array}$ & $\begin{array}{c}0.000 \\
(0.000)\end{array}$ & $\begin{array}{l}0.0000^{* *} \\
(0.000)\end{array}$ & $\begin{array}{c}0.000 \\
(0.000)\end{array}$ & $\begin{array}{c}0.002 \\
(0.000)\end{array}$ & $\begin{array}{l}-0.0022^{* * * *} \\
(0.000)\end{array}$ \\
\hline \multirow[t]{2}{*}{$p\left(C A P \_N G\right)$} & $t$ & $\begin{array}{c}0.012 \\
(0.009)\end{array}$ & $\begin{array}{c}0.009 \\
(0.002)\end{array}$ & & $\begin{array}{c}0.012 \\
(0.009)\end{array}$ & $\begin{array}{c}0.016 \\
(0.008)\end{array}$ & & $\begin{array}{c}0.012 \\
(0.009)\end{array}$ & $\begin{array}{c}0.006 \\
(0.000)\end{array}$ & \\
\hline & $t+1$ & $\begin{array}{c}0.006 \\
(0.006)\end{array}$ & $\begin{array}{c}0.010 \\
(0.002)\end{array}$ & $\begin{array}{l}-0.007 \\
(0.007)\end{array}$ & $\begin{array}{c}0.006 \\
(0.006)\end{array}$ & $\begin{array}{c}0.009 \\
(0.001)\end{array}$ & $\begin{array}{c}0.001 \\
(0.010)\end{array}$ & $\begin{array}{c}0.006 \\
(0.006)\end{array}$ & $\begin{array}{c}0.014 \\
(0.000)\end{array}$ & $\begin{array}{l}-0.0144^{* *} \\
(0.006)\end{array}$ \\
\hline$p\left(I C O V E R \_S M\right)$ & $t$ & $\begin{array}{c}0.317 \\
(0.037)\end{array}$ & $\begin{array}{c}0.268 \\
(0.010)\end{array}$ & & $\begin{array}{c}0.317 \\
(0.037)\end{array}$ & $\begin{array}{c}0.280 \\
(0.014)\end{array}$ & & $\begin{array}{c}0.317 \\
(0.037)\end{array}$ & $\begin{array}{c}0.237 \\
(0.003)\end{array}$ & \\
\hline \multirow[t]{2}{*}{$D O C$} & $t-1$ & $\begin{array}{c}1.664 \\
(0.085)\end{array}$ & $\begin{array}{c}1.600 \\
(0.032)\end{array}$ & & $\begin{array}{c}1.664 \\
(0.085)\end{array}$ & $\begin{array}{c}1.591 \\
(0.033)\end{array}$ & & $\begin{array}{c}1.664 \\
(0.085)\end{array}$ & $\begin{array}{c}1.746 \\
(0.012)\end{array}$ & \\
\hline & $t$ & $\begin{array}{c}1.794 \\
(0.085)\end{array}$ & $\begin{array}{c}1.666 \\
(0.034)\end{array}$ & $\begin{array}{c}0.064 \\
(0.070)\end{array}$ & $\begin{array}{c}1.794 \\
(0.085)\end{array}$ & $\begin{array}{c}1.665 \\
(0.036)\end{array}$ & $\begin{array}{c}0.056 \\
(0.067)\end{array}$ & $\begin{array}{c}1.794 \\
(0.085)\end{array}$ & $\begin{array}{c}1.900 \\
(0.002)\end{array}$ & $\begin{array}{l}-0.024 \\
(0.066)\end{array}$ \\
\hline \multirow[t]{2}{*}{ RES } & $t-1$ & $\begin{array}{c}2.435 \\
(0.067)\end{array}$ & $\begin{array}{c}2.435 \\
(0.018)\end{array}$ & & $\begin{array}{c}2.435 \\
(0.067)\end{array}$ & $\begin{array}{c}2.470 \\
(0.034)\end{array}$ & & $\begin{array}{r}2.435 \\
(0.067)\end{array}$ & $\begin{array}{r}2.390 \\
(0.007)\end{array}$ & \\
\hline & $t$ & $\begin{array}{c}2.377 \\
(0.066)\end{array}$ & $\begin{array}{c}2.557 \\
(0.019)\end{array}$ & $\begin{array}{l}-0.180^{* *} \\
(0.079)\end{array}$ & $\begin{array}{c}2.377 \\
(0.066)\end{array}$ & $\begin{array}{c}2.520 \\
(0.035)\end{array}$ & $\begin{array}{l}-0.107 \\
(0.076)\end{array}$ & $\begin{array}{c}2.377 \\
(0.066)\end{array}$ & $\begin{array}{r}2.406 \\
(0.002)\end{array}$ & $\begin{array}{l}-0.073 \\
(0.075)\end{array}$ \\
\hline \multirow[t]{2}{*}{$F I X$} & $t-1$ & $\begin{array}{c}0.308 \\
(0.015)\end{array}$ & $\begin{array}{c}0.292 \\
(0.005)\end{array}$ & & $\begin{array}{c}0.309 \\
(0.015)\end{array}$ & $\begin{array}{c}0.285 \\
(0.006)\end{array}$ & & $\begin{array}{c}0.308 \\
(0.015)\end{array}$ & $\begin{array}{c}0.312 \\
(0.001)\end{array}$ & \\
\hline & $t$ & $\begin{array}{c}0.311 \\
(0.015)\end{array}$ & $\begin{array}{c}0.297 \\
(0.005)\end{array}$ & $\begin{array}{l}-0.002 \\
(0.004)\end{array}$ & $\begin{array}{c}0.312 \\
(0.015)\end{array}$ & $\begin{array}{c}0.293 \\
(0.006)\end{array}$ & $\begin{array}{l}-0.004 \\
(0.004)\end{array}$ & $\begin{array}{c}0.311 \\
(0.015)\end{array}$ & $\begin{array}{c}0.318 \\
(0.001)\end{array}$ & $\begin{array}{l}-0.003 \\
(0.003)\end{array}$ \\
\hline
\end{tabular}


Table 10: Decomposition of Treatment Effects with Respect to ROA

This table presents the decomposition of treatment effects with respect to ROA. The figures for treatment effects of collateralized borrowers with respect to ROA are taken from Tables 4 and 8 . The treatment effects are decomposed using the following formula:

$\Delta R O A=\frac{\Delta S}{A_{t}}-\frac{\Delta C}{A_{t}}+\left(S_{t}-C_{t}\right) \cdot \Delta\left(\frac{1}{A}\right)+(\Delta S-\Delta C) \cdot \Delta\left(\frac{1}{A}\right)$,

where $S, C$, and $A$ represent gross sales, expenses, and total assets, respectively. The first term corresponds to the increase in gross sales, while the second corresponds to the reduction in expenses and the third corresponds to the reduction in total assets. The final term represents the cross-factor term.

\begin{tabular}{|c|c|c|c|c|c|}
\hline & \multirow{2}{*}{$\begin{array}{c}\text { Treatment } \\
\text { Effect w.r.t. } \\
\text { ROA } \\
\end{array}$} & \multicolumn{4}{|c|}{ Contributions to the Treatment Effect } \\
\hline & & $\begin{array}{l}\text { Increase in } \\
\text { Gross Sales }\end{array}$ & $\begin{array}{c}\text { Reduction in } \\
\text { Expenses }\end{array}$ & $\begin{array}{l}\text { Reduction in } \\
\text { Total Assets }\end{array}$ & Cross-Factor \\
\hline 5-Nearest Matching & 0.012 & -0.005 & 0.017 & 0.001 & -0.001 \\
\hline 10-Nearest Matching & 0.011 & -0.025 & 0.036 & 0.001 & -0.001 \\
\hline Kernel Matching & 0.011 & -0.024 & 0.034 & 0.000 & 0.000 \\
\hline Radius Matching & 0.008 & -0.029 & 0.037 & -0.001 & 0.001 \\
\hline
\end{tabular}


Appendix Table: Means for Collateralized and Non-Collateralized Borrowers (Including Firms that Partially Relied on Government Guarantees)

This table presents means of the main variables used in the probit estimations (Table 6). In order to control for the effects of government credit guarantees on collateral in a less stringent manner than in Table 2, we exclude from the sample only those borrowers whose entire loans supplied by their main bank are covered by government credit guarantee. In the column labeled " $C O L L(t)=1$," only firms that do not pledge collateral in year $t-1$ but do pledge collateral in year $t$ are included, while in the column labeled "COLL $(t)=0$," only firms that pledge collateral neither in year $t-1$ nor in year $t$ are included. The same applies with regard to guarantees in the columns labeled with "GUAR.” Definitions of the variables are provided in Table 1. Standard deviations are in parenthesis.

\begin{tabular}{|c|c|c|c|c|c|c|}
\hline & \multicolumn{6}{|c|}{ Mean } \\
\hline & \multicolumn{3}{|c|}{$\operatorname{COLL}(t-1)=0$} & \multicolumn{3}{|c|}{$\operatorname{GUAR}(t-1)=0$} \\
\hline & All & $\operatorname{COLL}(t)=1$ & $\operatorname{COLL}(t)=0$ & All & $\operatorname{GUAR}(t)=1$ & $\operatorname{GUAR}(t)=0$ \\
\hline$G U A R(t)$ & $\begin{array}{r}0.536 \\
(0.499)\end{array}$ & $\begin{array}{r}0.742 \\
(0.439)\end{array}$ & $\begin{array}{r}0.447 \\
(0.498)\end{array}$ & & & \\
\hline $\operatorname{GUAR}(t-1)$ & $\begin{array}{r}0.512 \\
(0.500)\end{array}$ & $\begin{array}{r}0.662 \\
(0.474)\end{array}$ & $\begin{array}{r}0.447 \\
(0.498)\end{array}$ & & & \\
\hline $\operatorname{COLL}(t)$ & & & & $\begin{array}{r}0.546 \\
(0.498)\end{array}$ & $\begin{array}{r}0.768 \\
(0.422)\end{array}$ & $\begin{array}{r}0.459 \\
(0.499)\end{array}$ \\
\hline $\operatorname{COLL}(t-1)$ & & & & $\begin{array}{r}0.546 \\
(0.498)\end{array}$ & $\begin{array}{r}0.717 \\
(0.451)\end{array}$ & $\begin{array}{r}0.480 \\
(0.500)\end{array}$ \\
\hline GOVGUAR(t) & $\begin{array}{r}0.190 \\
(0.392)\end{array}$ & $\begin{array}{r}0.427 \\
(0.496)\end{array}$ & $\begin{array}{r}0.086 \\
(0.281)\end{array}$ & $\begin{array}{r}0.130 \\
(0.337)\end{array}$ & $\begin{array}{r}0.374 \\
(0.485)\end{array}$ & $\begin{array}{r}0.032 \\
(0.175)\end{array}$ \\
\hline GOVGUAR(t-1) & $\begin{array}{r}0.168 \\
(0.374)\end{array}$ & $\begin{array}{r}0.352 \\
(0.479)\end{array}$ & $\begin{array}{r}0.088 \\
(0.284)\end{array}$ & $\begin{array}{r}0.100 \\
(0.301)\end{array}$ & $\begin{array}{r}0.269 \\
(0.444)\end{array}$ & $\begin{array}{r}0.032 \\
(0.177)\end{array}$ \\
\hline$R O A$ & $\begin{array}{r}0.022 \\
(0.050)\end{array}$ & $\begin{array}{r}0.018 \\
(0.053)\end{array}$ & $\begin{array}{r}0.024 \\
(0.049)\end{array}$ & $\begin{array}{r}0.020 \\
(0.048)\end{array}$ & $\begin{array}{r}0.016 \\
(0.047)\end{array}$ & $\begin{array}{r}0.022 \\
(0.049)\end{array}$ \\
\hline ICOVER & $\begin{array}{r}24.177 \\
(99.586)\end{array}$ & $\begin{array}{r}10.034 \\
(53.131)\end{array}$ & $\begin{array}{r}30.351 \\
(113.580)\end{array}$ & $\begin{array}{r}22.951 \\
(100.549)\end{array}$ & $\begin{array}{r}12.836 \\
(98.476)\end{array}$ & $\begin{array}{r}27.916 \\
(101.245)\end{array}$ \\
\hline CAP & $\begin{array}{r}0.321 \\
(0.241)\end{array}$ & $\begin{array}{r}0.308 \\
(0.228)\end{array}$ & $\begin{array}{r}0.326 \\
(0.247)\end{array}$ & $\begin{array}{r}0.337 \\
(0.237)\end{array}$ & $\begin{array}{r}0.330 \\
(0.236)\end{array}$ & $\begin{array}{r}0.339 \\
(0.237)\end{array}$ \\
\hline ROA_NG & $\begin{array}{r}0.205 \\
(0.404)\end{array}$ & $\begin{array}{r}0.272 \\
(0.446)\end{array}$ & $\begin{array}{r}0.176 \\
(0.381)\end{array}$ & $\begin{array}{r}0.199 \\
(0.400)\end{array}$ & $\begin{array}{r}0.241 \\
(0.428)\end{array}$ & $\begin{array}{r}0.181 \\
(0.385)\end{array}$ \\
\hline ICOVER_SM & $\begin{array}{r}0.271 \\
(0.445)\end{array}$ & $\begin{array}{r}0.380 \\
(0.487)\end{array}$ & $\begin{array}{r}0.223 \\
(0.417)\end{array}$ & $\begin{array}{r}0.277 \\
(0.448)\end{array}$ & $\begin{array}{r}0.382 \\
(0.486)\end{array}$ & $\begin{array}{r}0.226 \\
(0.419)\end{array}$ \\
\hline$C A P \_N G$ & $\begin{array}{r}0.034 \\
(0.182)\end{array}$ & $\begin{array}{r}0.042 \\
(0.202)\end{array}$ & $\begin{array}{r}0.031 \\
(0.173)\end{array}$ & $\begin{array}{r}0.018 \\
(0.134)\end{array}$ & $\begin{array}{r}0.026 \\
(0.159)\end{array}$ & $\begin{array}{r}0.015 \\
(0.121)\end{array}$ \\
\hline LnEMP & $\begin{array}{r}3.692 \\
(1.066)\end{array}$ & $\begin{array}{r}3.545 \\
(1.051)\end{array}$ & $\begin{array}{r}3.756 \\
(1.067)\end{array}$ & $\begin{array}{r}4.119 \\
(1.097)\end{array}$ & $\begin{array}{r}3.712 \\
(1.057)\end{array}$ & $\begin{array}{r}4.298 \\
(1.067)\end{array}$ \\
\hline LnLIAB & $\begin{array}{l}12.705 \\
(1.842)\end{array}$ & $\begin{array}{l}12.512 \\
(1.620)\end{array}$ & $\begin{array}{l}12.789 \\
(1.927)\end{array}$ & $\begin{array}{l}13.436 \\
(1.964)\end{array}$ & $\begin{array}{l}12.775 \\
(1.761)\end{array}$ & $\begin{array}{l}13.736 \\
(1.979)\end{array}$ \\
\hline$L O N G$ & $\begin{array}{r}0.398 \\
(0.356)\end{array}$ & $\begin{array}{r}0.469 \\
(0.324)\end{array}$ & $\begin{array}{r}0.366 \\
(0.365)\end{array}$ & $\begin{array}{r}0.434 \\
(0.329)\end{array}$ & $\begin{array}{r}0.504 \\
(0.332)\end{array}$ & $\begin{array}{r}0.402 \\
(0.323)\end{array}$ \\
\hline LAND & $\begin{array}{r}0.083 \\
(0.107)\end{array}$ & $\begin{array}{r}0.099 \\
(0.116)\end{array}$ & $\begin{array}{r}0.076 \\
(0.103)\end{array}$ & $\begin{array}{r}0.109 \\
(0.116)\end{array}$ & $\begin{array}{r}0.128 \\
(0.118)\end{array}$ & $\begin{array}{r}0.100 \\
(0.115)\end{array}$ \\
\hline $\mathrm{CASH}$ & $\begin{array}{r}0.190 \\
(0.149)\end{array}$ & $\begin{array}{r}0.199 \\
(0.143)\end{array}$ & $\begin{array}{r}0.186 \\
(0.151)\end{array}$ & $\begin{array}{r}0.160 \\
(0.137)\end{array}$ & $\begin{array}{r}0.198 \\
(0.143)\end{array}$ & $\begin{array}{r}0.144 \\
(0.131)\end{array}$ \\
\hline RATE & $\begin{array}{r}0.021 \\
(0.022)\end{array}$ & $\begin{array}{r}0.023 \\
(0.015)\end{array}$ & $\begin{array}{r}0.020 \\
(0.024)\end{array}$ & $\begin{array}{r}0.020 \\
(0.020)\end{array}$ & $\begin{array}{r}0.024 \\
(0.021)\end{array}$ & $\begin{array}{r}0.018 \\
(0.019)\end{array}$ \\
\hline OWNER & $\begin{array}{r}0.578 \\
(0.494)\end{array}$ & $\begin{array}{r}0.709 \\
(0.455)\end{array}$ & $\begin{array}{r}0.520 \\
(0.500)\end{array}$ & $\begin{array}{r}0.453 \\
(0.498)\end{array}$ & $\begin{array}{r}0.754 \\
(0.431)\end{array}$ & $\begin{array}{r}0.336 \\
(0.473)\end{array}$ \\
\hline BANKS & $\begin{array}{r}3.997 \\
(3.643)\end{array}$ & $\begin{array}{r}3.751 \\
(3.279)\end{array}$ & $\begin{array}{r}4.105 \\
(3.789)\end{array}$ & $\begin{array}{r}5.300 \\
(5.911)\end{array}$ & $\begin{array}{r}4.193 \\
(3.964)\end{array}$ & $\begin{array}{r}5.727 \\
(6.459)\end{array}$ \\
\hline LnDURATION & $\begin{array}{r}3.005 \\
(0.845)\end{array}$ & $\begin{array}{r}3.086 \\
(0.816)\end{array}$ & $\begin{array}{r}2.970 \\
(0.856)\end{array}$ & $\begin{array}{r}3.279 \\
(0.691)\end{array}$ & $\begin{array}{r}3.279 \\
(0.729)\end{array}$ & $\begin{array}{r}3.280 \\
(0.675)\end{array}$ \\
\hline Number of observations & 701 & 213 & 488 & 928 & 308 & 620 \\
\hline
\end{tabular}

